\title{
Thalassic Rotifers from the United States: Descriptions of Two New Species and Notes on the Effect of Salinity and Ecosystem on Biodiversity
}

\author{
Francesca Leasi ${ }^{1, *(D)}$ and Willem H. De Smet ${ }^{2}$ \\ 1 Department of Biology, Geology and Environmental Science, University of Tennessee, Chattanooga, \\ 615 McCallie Ave, Chattanooga, TN 37403, USA \\ 2 Department of Biology. ECOBE, University of Antwerp, Universiteitsplein 1, 2610 Wilrijk, Belgium; \\ willem.desmet@uantwerpen.be \\ * Correspondence: Francesca-Leasi@utc.edu
}

http://zoobank.org:pub:7679CE0E-11E8-4518-B132-7D23F08AC8FA

Received: 26 November 2019; Accepted: 7 January 2020; Published: 13 January 2020

\begin{abstract}
This study shows the results of a rotifer faunistic survey in thalassic waters from 26 sites located in northeastern U.S. states and one in California. A total of 44 taxa belonging to 21 genera and 14 families were identified, in addition to a group of unidentifiable bdelloids. Of the fully identified species, 17 are the first thalassic records for the U.S., including Encentrum melonei sp. nov. and Synchaeta grossa sp. nov., which are new to science, and Colurella unicauda Eriksen, 1968, which is new to the Nearctic region. Moreover, a refined description of Encentrum rousseleti (Lie-Pettersen, 1905 ) is presented. During the survey, we characterized samples by different salinity values and ecosystems and compared species composition across communities to test for possible ecological correlations. Results indicate that both salinities and ecosystems are a significant predictor of rotifer diversity, supporting that biodiversity estimates of small species provide fundamental information for biomonitoring. Finally, we provide a comprehensive review of the diversity and distribution of thalassic rotifers in the United States. The results of the present study increase the thalassic rotifer record for the U.S. from about 105 (87 at species level) to 124 (106 at species level) taxa.
\end{abstract}

Keywords: marine; brackish; meiofauna; microscopic invertebrates; North America; taxonomy; ecology

\section{Introduction}

Phylum Rotifera is a group of micrometazoans including 2149 species (inclusive subspecies) distributed worldwide in almost every type of aquatic and semi-aquatic habitat, and containing two major groups: Bdelloidea and Monogononta; Seisonacea represents a small group of four epizoic marine species [1-6]. Most of the known rotifer taxa are freshwater, and only about 455 taxa have been reported from saline ecosystems, both thalassic and athalassic [6-11]. The relatively low richness of saltwater rotifers may reflect the actual paucity of the group; however, results might be likely misrepresented by a clear sampling bias [6,12]. In fact, the majority of rotifer investigations have been performed in freshwater biotas, with rotifers being traditionally neglected in saltwater habitats [6]. Yet, not surprisingly, the diversity of brackish and marine rotifers seems to be particularly high in areas around Europe, reflecting the geographic distribution of the investigators $[10,13,14]$, a phenomenon known as the "rotiferologist effect" [12].

In the United States, marine biodiversity is well investigated; however, as also stated by Fautin et al. [15], the most documented and better described marine taxa appear to be the ones that are larger and of commercial importance (but see the study on marine coastal tardigrades by 
Miller and Perry [16]). Most studies focusing on biodiversity include rotifers in larger groups, usually called "other invertebrates" [15]. This pattern is likely due to taxonomic inventories based on records scattered in space and time, but it also supports the perception that microscopic invertebrates are underappreciated and largely neglected in biodiversity studies $[9,17]$.

Taxonomic investigations on thalassic rotifers, i.e., both marine and brackish, of the U.S. almost exclusively concern Monogononta. The first study dates back to 1904 when Smith described Synchaeta bicornis from Louisiana, Gulf of Mexico [18]. Subsequent contributions are mostly limited to the first half of the 20th century and mainly focused on the thalassic environments of Maine and New Jersey (Northeast U.S. Continental Shelf) [19-28]. Further information on the rotifers of the Gulf of Mexico was added by Ahlstrom [29,30], Koste [31], and Turner [32,33]. A single study has discussed rotifers from Alaska [34]. Occasional information on thalassic rotifers from the Hawaiian Islands was provided by Weber [35], Hauer [36], and Jersabek [37]. A new seisonid, collected off the coast of California, was more recently described by Leasi et al. [38]. Additional or occasional information is mostly included in more general ecological investigations of plankton. Ecological studies, usually treating rotifers besides other organisms, are largely restricted to the plankton of the estuaries of the Chesapeake Bay basin, and mostly refer to rotifers as a group or at the genus level only (e.g., [39-41]).

The present study shows the results of a taxonomic and ecological survey of 26 thalassic sites from the northeastern U.S. states and one in California. Rotifer communities were collected, analyzed taxonomically, and compared across different ecosystems and salinities to test for possible ecological correlations. Four species were new to science, of which two are described hereafter. During the survey, we found several specimens of Encentrum rousseleti (Lie-Pettersen, 1905), which allowed us to refine the description of its external morphology and masticatory hard parts. In addition, we present a comprehensive review of the diversity and distribution of thalassic rotifers reported in U.S. waters to date.

\section{Materials and Methods}

\subsection{Sampling}

A total of 27 saltwater sites were sampled across seven U.S. states between March and September 2012 (Table 1, Figure 1). Sites were mainly from the Northeast Continental Shelf, including Connecticut (two sites), Maine (two sites), Massachusetts (four sites), New Hampshire (two sites), New Jersey (13 sites), and New York (three sites); one site was from California Current. Ecosystems consisted of littoral beaches to salt and brackish channels, backshore areas, circumscribed saline ponds, and marshes. All samples were characterized by either floating or benthic green algae (gutweed, Ulva sp.), salt grass (Distichlis sp.), and wrack (Fucus sp.). Although samples were inevitably collected together with some surrounding water and sediment, the identified rotifers shall be considered periphytic. Samples were collected by hand with jars in three replicates, kept in refrigerated coolers at a temperature of about $10^{\circ} \mathrm{C}$, and taken to the laboratory at the Academy of Natural Sciences of Drexel University in Philadelphia, where they were processed within a few days. Each replicate was investigated separately and results were pooled together. For each site, geographical coordinates were recorded, ecosystem observed, and salinity measured in the field with a $\pm 0.5 \%$ o resolution $\mathrm{VWR}^{\circledR}$ International Brand Hand Held Refractometer (Table 1). For a gross general survey, we arbitrarily considered "saltwater" to be water with a salinity equal to or higher than $0.5 \%$. Specifically, we distinguished "brackish waters" as waters with a salinity of $20 \%$ o or lower and "marine waters" as those with salinity above $20 \%$ o [42,43]. For a more detailed analysis of salinity (S), we followed the Venice System [44], recognizing oligohaline $(0.5 \%$ o $<\mathrm{S} \sim 5 \%$ o), mesohaline $(5 \%$ o $<\mathrm{S} \sim 18 \%$ o), polyhaline $(18 \%$ o $<\mathrm{S} \sim$ $30 \%$ ), and euhaline waters ( $30 \%$ o $<\mathrm{S} \sim 40 \%$ o). Ecosystems sampled (Table 1, Figure 1) were grouped into three major types: (i) Coast, including habitats that are not expected to be affected by water fluctuations. For example, coastal waters, internal harbors, exposed or sheltered beaches, backshore areas, and channels permanently connected to the ocean; (ii) Ponds, including habitats that are likely 
affected by seasonal water fluctuations. For example, circumscribed basins and either natural or artificial ponds not directly connected to the ocean or not disturbed by maritime activities; (iii) Marshes, defined as temporary areas of coastal vegetation affected by regular and frequent seawater flooding and desiccation. Out of the 27 sampled sites, 12 were saline marshes, 8 sites were located on the coast or permanently connected to the open ocean, and 7 were circumscribed ecosystems or ponds (Figure 1). Nine sites were characterized by brackish and 18 by marine water, with salinity values ranging between $2 \%$ and $40 \%$ : four oligohaline, four mesohaline, eleven polyhaline, and eight euhaline.

A

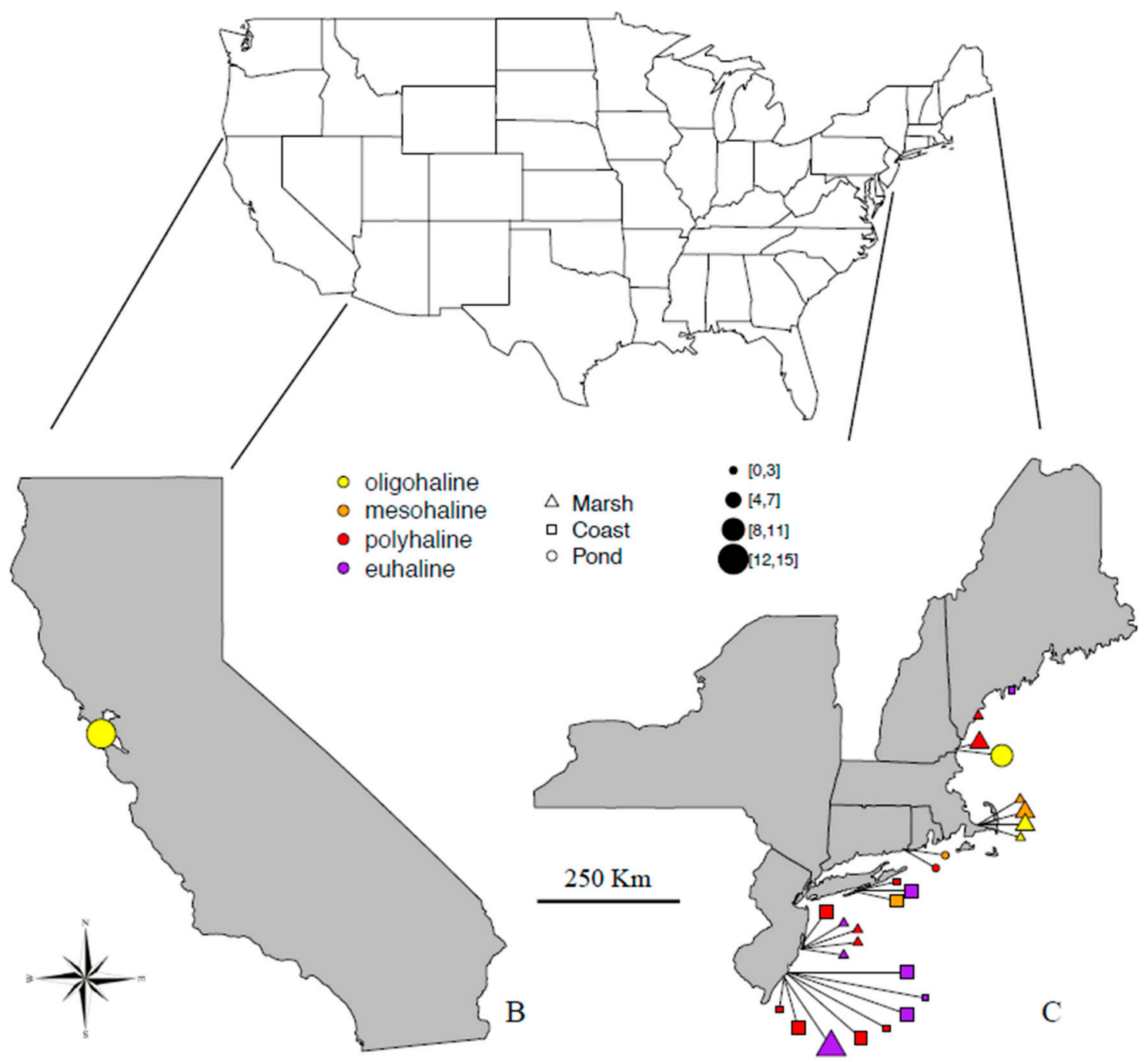

Figure 1. Map indicating sampling sites: (A) outline of the United States; (B) California. (C) Northeast U.S. Locations are indicated using different colors for salinities according to the Venice Classification and different shapes for the three types of ecosystem. The size summarizes the number of species found at each site. 
Table 1. List of sites and ecosystems where samples were collected. Coordinates (in decimal degree format), salinity values and classifications, ecosystems, and date of sampling are shown.

\begin{tabular}{|c|c|c|c|c|c|c|c|c|c|}
\hline Site ID & State * & Site & Salinity \%o & $\begin{array}{l}\text { Salinity } \\
\text { Group }\end{array}$ & Ecosystem & Lat $\mathbf{N}$ & Long W & $\begin{array}{c}\text { Venice } \\
\text { Classification }\end{array}$ & $\begin{array}{c}\text { Date of Sampling } \\
\mathrm{mm} / \mathrm{dd} / 2012\end{array}$ \\
\hline 100 & NJ & Barnegat Bay & 34 & Marine & Marsh & 39.7917 & 74.113 & euhaline & $03 / 30$ \\
\hline 101 & NJ & Barnegat Bay & 40 & Marine & Marsh & 39.7904 & 74.1150 & euhaline & $03 / 30$ \\
\hline 102 & NJ & Barnegat Bay & 30 & Marine & Marsh & 39.7905 & 74.1171 & polyhaline & $03 / 30$ \\
\hline 103 & NJ & Barnegat Bay & 30 & Marine & Marsh & 39.7909 & 74.1171 & polyhaline & $03 / 30$ \\
\hline 104 & NJ & Barnegat Bay & 24 & Marine & Marsh & 39.8718 & 74.0822 & polyhaline & $03 / 30$ \\
\hline 118 & NJ & Brigantine & 34 & Marine & Coast & 39.4192 & 74.3796 & euhaline & $06 / 05$ \\
\hline 119 & NJ & Brigantine & 34 & Marine & Coast & 39.4191 & 74.3800 & euhaline & $06 / 05$ \\
\hline 120 & NJ & Brigantine & 34 & Marine & Coast & 39.4191 & 74.3800 & euhaline & $06 / 05$ \\
\hline 121 & NJ & Brigantine & 30 & Marine & Coast & 39.3947 & 74.4030 & polyhaline & $06 / 05$ \\
\hline 122 & NJ & Brigantine & 30 & Marine & Coast & 39.3949 & 74.4026 & polyhaline & $06 / 05$ \\
\hline 123 & NJ & Calvert & 30 & Marine & Coast & 39.3459 & 74.4765 & polyhaline & $06 / 05$ \\
\hline 124 & NJ & Calvert & 30 & Marine & Coast & 39.3460 & 74.4761 & polyhaline & $06 / 05$ \\
\hline 125 & NJ & Calvert & 34 & Marine & Marsh & 39.3526 & 74.4790 & euhaline & $06 / 05$ \\
\hline 126 & CA & San Francisco & 4 & Brackish & Pond & 37.7803 & 122.5139 & oligohaline & 07/09 \\
\hline 130 & NY & Fire Island & 30 & Marine & Pond & 40.6927 & 72.9882 & polyhaline & $07 / 31$ \\
\hline 131 & NY & Fire Island & 32 & Marine & Pond & 40.6939 & 72.9868 & euhaline & $07 / 31$ \\
\hline 132 & NY & Fire Island & 8 & Brackish & Pond & 40.6915 & 72.9863 & mesohaline & $07 / 31$ \\
\hline 139 & ME & Boothbay & 32 & Marine & Coast & 43.8422 & 69.6545 & euhaline & $09 / 28$ \\
\hline 140 & ME & Biddeford & 20 & Brackish & Marsh & 43.4395 & 70.3654 & polyhaline & $09 / 28$ \\
\hline 141 & $\mathrm{NH}$ & Hampton & 30 & Marine & Marsh & 42.9295 & 70.8405 & polyhaline & $09 / 28$ \\
\hline 142 & $\mathrm{NH}$ & Hampton & 2 & Brackish & Pond & 42.9078 & 70.8667 & oligohaline & $09 / 28$ \\
\hline 143 & MA & $\begin{array}{l}\text { Cape Cod } \\
\text { Barnstable }\end{array}$ & 6 & Brackish & Marsh & 41.7338 & 70.3794 & mesohaline & $09 / 30$ \\
\hline 144 & MA & $\begin{array}{l}\text { Cape Cod } \\
\text { Barnstable }\end{array}$ & 10 & Brackish & Marsh & 41.7333 & 70.3794 & mesohaline & $09 / 30$ \\
\hline 145 & MA & $\begin{array}{l}\text { Cape Cod } \\
\text { Barnstable }\end{array}$ & 3 & Brackish & Marsh & 41.7332 & 70.3794 & oligohaline & $09 / 30$ \\
\hline 146 & MA & $\begin{array}{l}\text { Cape Cod } \\
\text { Barnstable }\end{array}$ & 4 & Brackish & Marsh & 41.7333 & 70.3794 & oligohaline & $09 / 30$ \\
\hline 147 & CT & Mystic & 10 & Brackish & Pond & 41.3563 & 71.9644 & mesohaline & $09 / 30$ \\
\hline 148 & CT & Mystic & 30 & Marine & Pond & 41.3562 & 71.9648 & polyhaline & $09 / 30$ \\
\hline
\end{tabular}

* CA, California; CT, Connecticut; MA, Massachusetts; ME, Maine; NH, New Hampshire; NJ, New Jersey; NY, New York. 


\subsection{Taxonomic Analysis}

Specimens were extracted by siphoning off the water just above the residue sediment and vegetation [45]. Live material was studied using dissecting (Leica M125) and light microscopes (Leica DM6B), followed by fixation with formalin. The major works used for identification of rotifer species were by Koste [46], Nogrady et al. [47], Segers [48], De Smet [49,50], Nogrady and Segers [51], and Fontaneto et al. [7]. The nomenclature of the rotifers followed the proposal of Segers et al. [52] and Jersabek et al. [53]. Fixed specimens were drawn using a Leitz Orthoplan microscope equipped with camera lucida. Preparation of the rotifer trophi was done following De Smet [54], and scanning electron microscopy (SEM) was performed with a Philips SEM 515 operated at $20 \mathrm{kV}$. The terminology of the trophi elements of Synchaeta followed De Smet (in prep.); elements are indicated in the figures of the species description.

\subsection{Data Analysis}

We expected that type of ecosystem, as well as salinity, might affect species composition and species distribution. Therefore, we tested for the statistical significance of rotifer communities across (1) the three types of ecosystems, broadly defined and described above as coast, ponds, and marshes, and (2) salinity values. Differences in community structure ( $\beta$-diversity) between samples were measured using the Jaccard dissimilarity index, therefore, we partitioned differences in community composition among variables using a permutational multivariate analysis of variance (PERMANOVA) approach and tested significance by permuting the data (999 permutations, function adonis in the $\mathrm{R}$ package Vegan 2.4-5 [55]). Pairwise comparisons between group levels were performed with the function pairwise.perm.manova (package RVAideMemoire 0.9-72 [56]). Moreover, we performed a two-dimensional non-metric multidimensional scaling ordination (nMDS) to investigate community dissimilarities. The Jaccard dissimilarity index was used to generate a rank dissimilarity matrix, which was converted into an nMDS [55,57]. Rotifers of each site were considered as a unique assemblage using the $R$ package Vegan 2.4-5 [55]. Furthermore, we used analysis of variance (ANOVA), implemented in $\mathrm{R}$, to test whether the type of ecosystem is a significant predictor of salinity [58].

A few taxa could only be identified to the genus level and are included in the analyses as such. Six bdelloid specimens were not identified because of their contracted body resulting from fixation in formalin, and not allowing for any diagnostic investigation. Therefore, they were not included in the analyses, although we are aware they might represent further species. Biological units were organized in presence/absence (incidence) datasets. To test the effect of the sample size, a linear model was used to correlate the number of investigated samples from each of the three ecosystems, as well as from each of the four salinity groups according to the Venice System, with species diversity measured in both richness ( $\alpha$-diversity) and community structure ( $\beta$-diversity).

\subsection{Compilation of Checklist of U.S. Thalassic Rotifer Taxa}

The checklist of thalassic rotifers from the United States (Supplementary Table S1) was based on a compilation of all published records known to us [3,18-41,59-79], in addition to information available in the Frank J. Myers Rotifera Collection at the Academy of Natural Sciences of Drexel University [79], the Rotifer World Catalog [3], a few hitherto unpublished occasional records by one of us (W.H.D.S.), and the species found in the present survey. We must emphasize that many literature reports concern unverifiable records. The biogeographical system for marine regions of the U.S. of Fautin et al. [15] was used to summarize rotifer distribution.

\section{Results}

\subsection{Taxonomic Analysis}

Two species, new to science, are described below. Encentrum melonei sp. nov. was found in euhaline waters from New Jersey and Maine. Synchaeta grossa sp. nov. was present in mesohaline, 
polyhaline, and euhaline waters from New Jersey, Maine, and Massachusetts. Moreover, a refined description of the external morphology and masticatory hard parts of Encentrum rousseleti is presented.

Systematics

Class EUROTATORIA De Ridder, 1957

Subclass MONOGONONTA Plate, 1889

Order PLOIMA Hudson and Gosse, 1886

Family Dicranophoridae Harring, 1913

Genus Encentrum Ehrenberg, 1838

Encentrum melonei De Smet and Leasi, new species

Diagnosis: Large-sized Encentrum about 205-210 $\mu \mathrm{m}$ long (slightly contracted); trophi subgenus Encentrum type; rostrum small, rounded; corona oblique; tail very short, somewhat straight-cut; toes conical, indented near mid-length, bases swollen, tubuli distinct; rami very weakly asymmetrical, median rami opening wedge-shaped with two marginal slightly asymmetrical teeth, left tooth fairly acute, right one blunt; intramallei with small additional platelet medio-laterally.

Material examined: Six females collected from New Jersey (sites 124 and 125; Table 1) and one from Maine (site 139, Table 1).

Type locality: New Jersey, Calvert Ventnor City, 39.346071 N, -74.476131 E; site 124; collected 5 June 2012, salinity $=30 \%$ o. Lagoon in estuarine system surrounded by wetland in close proximity to salt marsh islands and connected to the Atlantic Ocean by a channel. Samples characterized by a variety of benthic seaweeds, viz. sea lettuce (Ulva lactuca), wrack (Fucus sp.), and gutweed (Ulva sp.).

Holotype: An adult female in a permanent glycerin glass slide mount deposited in the Royal Belgian Institute of Natural Sciences (R.B.I.N.S.), Brussels, Belgium, IG. 34111, RIR.283

Paratypes: An adult female in R.B.I.N.S (IG. 34111, RIR.284), and one in the Department of Biology, University of Antwerp; four stubs, each with trophi preparation for SEM in the Department of Biology, University of Antwerp.

Etymology: The species is named after Prof. Dr. Giulio Melone (University of Milan, Italy), in recognition of his contributions to rotiferology. http://zoobank.org:act:476BBF80-33AD-4F33-B01CA5E69EF212F1.

Description of female: Body (Figure 2A,B) stout fusiform in dorsal view, broadest near mid-length, in lateral view weakly arched. Head c. 1/3 total length, offset from trunk by distinct neckfold, almost in line with trunk; weak longitudinal furrows dorso-laterally. Dorsal antenna at $1 / 3$ from neckfold. Rostrum small, rounded. Corona oblique. Trunk with distinct distal pseudosegment and weak longitudinal dorso-lateral furrows terminating in shallow dorso-lateral expansions near posterior $1 / 3$. Lateral antennae near distal margin of main trunk pseudosegment. Tail very short, somewhat straight-cut in dorsal view. Foot short, broad, a single pseudosegment, with small caudal antenna between toes. Toes (Figure 2C,D) c. 1/8 total length, in dorsal view conical, symmetrically indented near mid-length, terminating in distinct tubuli; in lateral view dorsal medial indentation less pronounced. Brain saccate, with distinct retrocerebral sac. Proventriculus present. Gastric glands large, spherical, stalks apparently absent. Bladder spherical. Pedal glands extending into trunk, elongated bean-shaped with small spherical reservoirs. Vitellarium with eight spherical nuclei.

Trophi (Figures 2E and 3) of subgenus Encentrum type; large, elongated, fairly slender. Rami very weakly asymmetrical, rami outline longer than wide, ratio length: width of closed rami $\sim 1.6$; dorsal outer margin of rami straight laterally, angular postero-laterally, forming short blunt alulae; ventral outer margins, in particular of subbasal chambers, converging towards fulcrum; rami laterally fairly concave, with distinct ridge between subbasal and basal chambers (Figure 3F: r); carina rami absent; median rami opening wedge-shaped with two marginal slightly asymmetrical teeth formed by the protruding distal ends of the subbasal chambers, left tooth fairly acute, right one blunt; basal chambers dorsally with small ellipsoid basifenestrae; subbasal chambers caudally with small, rounded subbasifenestrae. Each ramus with single, slightly offset apical tooth set at almost right angle to trophi 
axis; cardal apophyses very small to absent. Prior to apical teeth a preuncinal tooth set at a right angle to trophi axis; preuncinal teeth with elongated triangular head and short shaft forming right angle; base of head very weakly swollen; distal end of shaft with small cardal apophysis. Fulcrum long, slightly longer than ramus, in dorsal/ventral view distal end slightly widening, widening indented distally; in lateral view with broader base, gradually tapering, continuing parallel-sided. Unci medium long, composed of single uncinus, slightly curved, head as long as shaft, with small dorsal and ventral apophyses. Intramallei long (Figure 3E: im), sock-shaped, with relatively long, rounded medio-lateral basal expansion showing opening at the inner median side, and bearing fused additional platelet medially (Figure 3E: ap) at anterior margin; inner side expanded, fitting lateral concavity of rami. Supramanubria apparently absent. Manubria slightly less incus length, stout, rod-shaped, proximal 2/3 straight, distal 1/3 incurving with crutched cauda, head short, with small triangular expansion showing fairly large median opening.
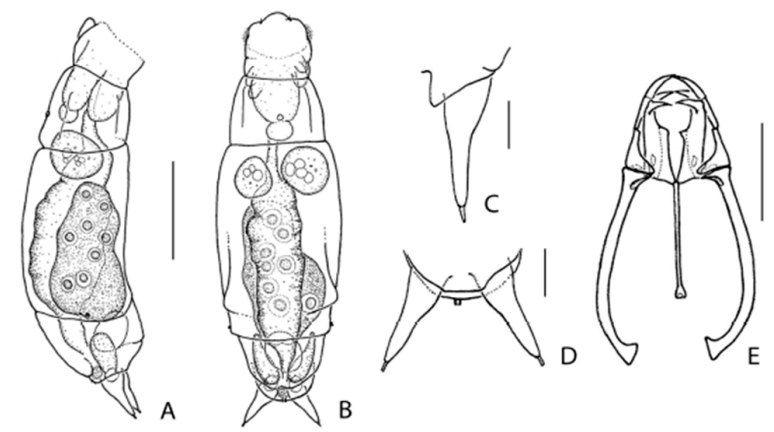

Figure 2. Encentrum melonei sp. nov. (A) Female, lateral. (B) Female, dorsal. (C) Toe, lateral, right. (D) Toes, dorsal. (E) Trophi, ventral. Scale bars: (A,B): $50 \mu \mathrm{m}$; (C-E): $10 \mu \mathrm{m}$.

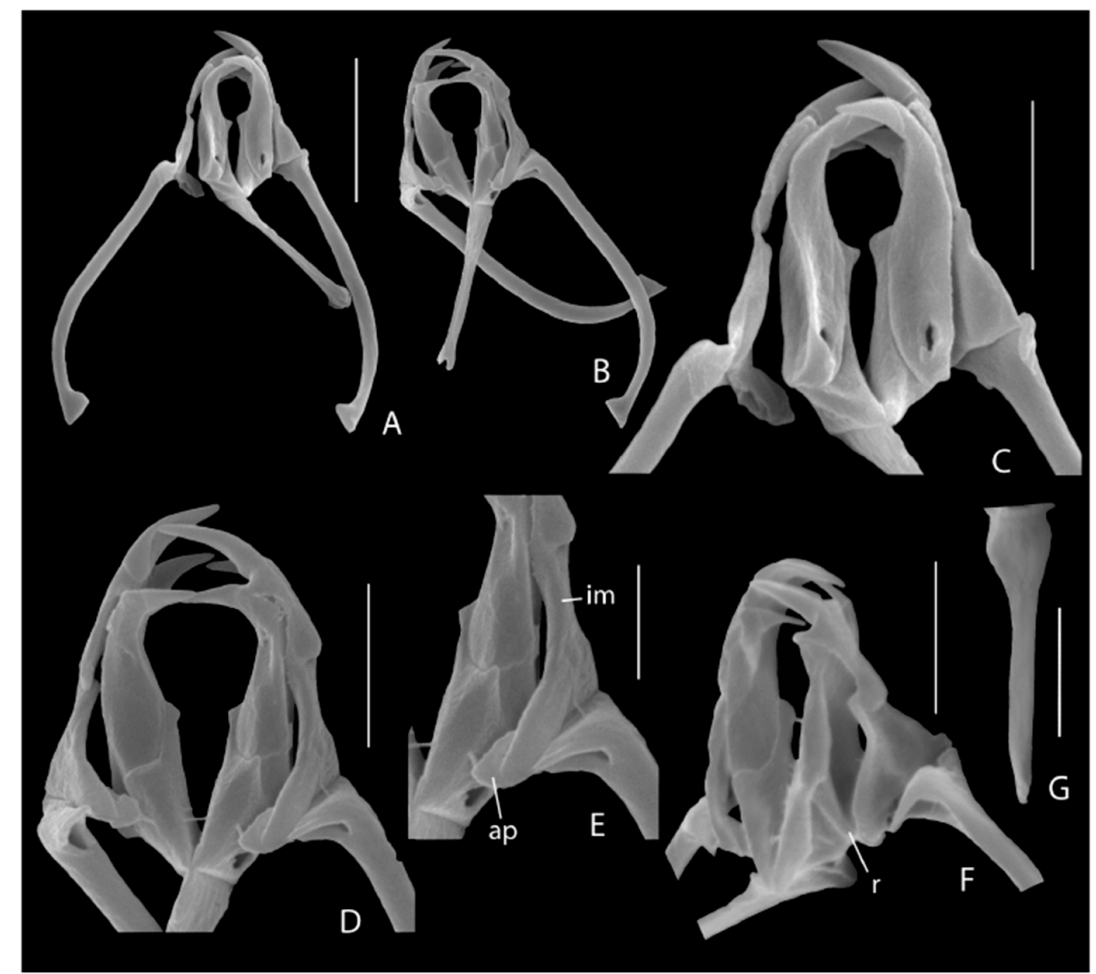

Figure 3. Encentrum melonei sp. nov., scanning electron microscopy (SEM) photographs of trophi. (A) Complete set, dorsal. (B) Complete set, ventral. (C) Detail, dorsal. (D) Detail, ventral. (E) Left intramalleus, ventro-lateral. (F) Detail, ventro-lateral. (G) Fulcrum, lateral. ap: additional platelet; im: intramalleus; r: ridge between subbasal and basal chamber. Scale bars: (A,B): $10 \mu \mathrm{m}$; (C-G): $5 \mu \mathrm{m}$. 
Measurements: Total length (slightly contracted) $(\mathrm{N}=5): 205-210 \mu \mathrm{m}$, toe $23-27 \mu \mathrm{m}$; trophi $(\mathrm{N}=4)$ ): length 26.8-29.0 $\mu \mathrm{m}$ (mean $27.7 \mu \mathrm{m}$ ), ramus 9.6-10.2 $\mu \mathrm{m}$ (mean $9.9 \mu \mathrm{m})$, fulcrum 10.3-11.5 $\mu \mathrm{m}$ (mean $11.2 \mu \mathrm{m}$ ), uncus 6.4-7.1 $\mu \mathrm{m}$ (mean $6.8 \mu \mathrm{m}$ ), preuncinal tooth (tooth $\times$ shaft) $2.1-3.4 \times 2.1-2.6 \mu \mathrm{m}$ (mean $2.3 \times 2.9 \mu \mathrm{m}$ ), intramalleus $\sim 5-6.3 \mu \mathrm{m}$, manubrium 19.4-20.3 $\mu \mathrm{m}$ (mean $19.6 \mu \mathrm{m}$ ).

Distribution and ecology: Encentrum melonei sp. nov. is, to date, only known from New Jersey (Atlantic County, Ventnor City) and Maine (Lincoln County, Boothbay). Sample sites are located either backshore, although connected to the open Atlantic Ocean (New Jersey, site 124), in marshes (New Jersey, site 125), or directly on the coast (Maine, site 139). Samples were collected in June and September at salinities ranging from $30 \%$ o to $34 \%$, indicating that it may be a truly marine (euhaline) species.

Comments: The new species superficially resembles the larger species belonging to the subgenus Encentrum [50], but is easily differentiated by its characteristic toes and the presence of slightly asymmetrical median rami teeth. Judging from the shape of the species-specific trophi, the next related species of E. melonei sp. nov. is Encentrum limicola Otto, 1936, which lacks median rami teeth, and E. algente Harring, 1922, showing rather pronounced symmetrical median rami teeth. The small additional platelet fused to the intramallei present in the new species have not been demonstrated in the 12 Encentrum (Encentrum) species studied to date by SEM [50,80,81]. Their medio-lateral position at the antero-proximal end of the intramallei suggest that it may be vestigial supramanubria.

Class EUROTATORIA De Ridder, 1957

Subclass MONOGONONTA Plate, 1889

Order PLOIMA Hudson and Gosse, 1886

Family Dicranophoridae Harring, 1913

Genus Encentrum Ehrenberg, 1838

Encentrum rousseleti (Lie-Pettersen, 1905)

Diglena rousseleti Lie-Pettersen 1905; 34-35, text Figure 3, pl. 2, Figures 9-11.

Material examined: New Jersey (site 125; marsh; $S=34 \%$ ) and Massachusetts (site 144; marsh; $\mathrm{S}=10 \%$ ); additional material: several specimens from a brackish puddle at Ambleteuse, the Channel, France.

The species was rather poorly described by Lie-Pettersen [62] from a brackish puddle at Radö, Bergen, Norway. Remane ([13]: 138, Figure 162; 1933: 301, Figure 23a) presented more detailed figures, but without giving descriptions of the specimens, apparently collected in the Kieler Bucht, Germany. Althaus ([82]: 136-137, Figure 32) provided an extensive description, based on animals collected from an inland saline ditch at Burgliebenau, near Merseburg, Germany. The present study of specimens from U.S. and material from France allows for some corrections and additions to the description of E. rousseleti, as presented in the revision by De Smet [50], which was based on the above-mentioned studies. The morphology of the small trophi, at the limit of light microscopy, is redescribed based on SEM.

Emendations to female morphology: (Figure 4A-G). The rostrum (Figure $4 \mathrm{D}$ ) is not broadly rounded uniformly but weakly flattened in the middle. A large caudal antenna (Figure 4F,G: ca), not mentioned before, is present dorsally between the bases of the toes. The toes (Figure $4 \mathrm{E}-\mathrm{G}$ ) are in both ventral/dorsal and lateral view almost parallel-sided for about 2/3 of their basal part, whereupon the inner, respectively ventral, margins continue in a straight way, and the outer, respectively dorsal, margins curve to continue in a straight line towards a motile acute tip, shaped as a pseudoclaw. The toes show distinct round reservoirs at $c$. 1/3 from the tip. Two red eyespots (Figure 4C), in dorsal view reniform to rounded, laterally at the base of the rostrum; each of them occasionally accompanied by a small roundish red eyespot. The number of nuclei in the vitellarium vary between 16 and 34 (18-20 in literature). 


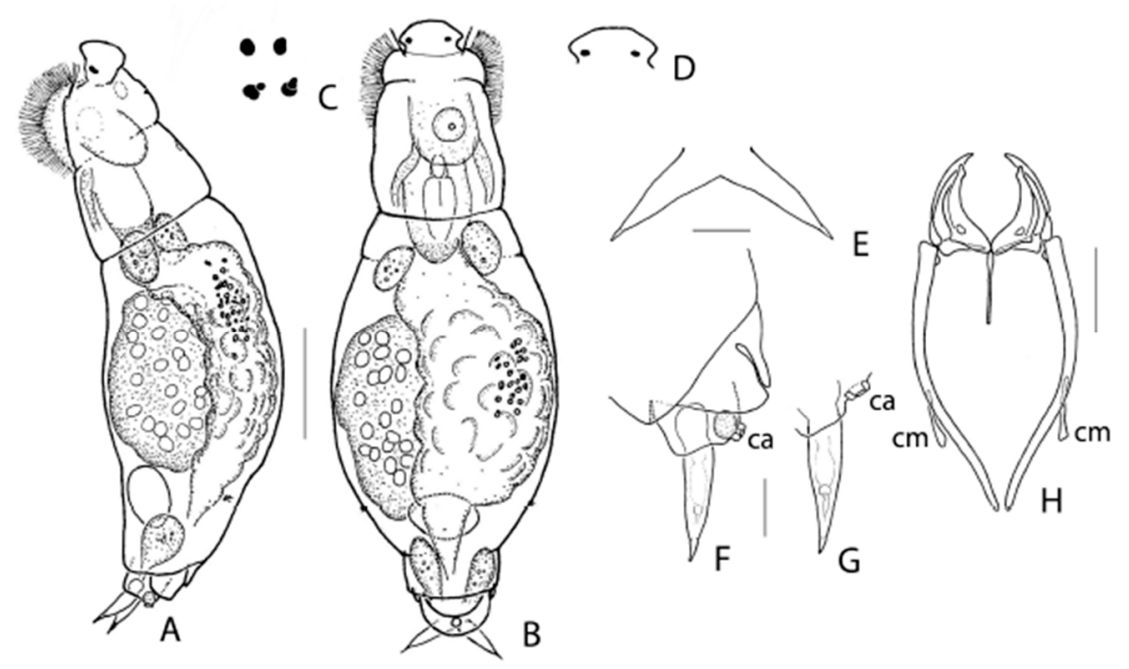

Figure 4. Encentrum rousseleti (Lie-Pettersen, 1905). (A) Female (slightly contracted), lateral. (B) Female, dorsal. (C) Eyespots (left), different shapes. (D) Rostrum, detail, dorsal. (E) Toes, dorsal. (F,G) Toes, lateral left. (H) Trophi, dorsal. ca: caudal antenna; cm: calcar manubrii. Scale bars: (A,B): 50 m; (E-G): $10 \mu \mathrm{m}$.

Redescription of the trophi by S.E.M.: (Figure 5). Major differences to former descriptions are indicated between square brackets. Rami outline oboval with blunt dorsal postero-lateral alulae (alulae absent) and short latero-dorsal projection at the outer margin of basifenestrae (Figure 5F); median rami opening broad lenticular. Rami curved, broad and high at base, tapering to slightly outcurved blunt tips, prior to tips a short, blunt medio-lateral tooth (rami with simple acute tip). Rami lateral margins concave, showing pronounced dorsal and ventral edges (not mentioned). Basifenestrae and subbasifenestrae small. Preuncinal teeth absent. Fulcrum c. 4/5 ramus length (c. $1 / 2$ ramus length), narrow and almost parallel-sided in dorsal/ventral view, its proximal 1/3 with additional layer of lateral sclerofibrillae responsible for weak thickening (anterior half expanded); in lateral view broad at base, only weakly narrowing towards the more or less rounded distal end (posterior edge straight). Unci long, c. 4/5 ramus length, each composed of two slender, slightly curved uncini (Figure 5I) with long shafts and weakly offset heads (unci single-toothed); ventral uncini largest with large more or less acute head c. 1/5 uncus length, shaft showing sutura uncini; dorsal uncini with small rounded head $c$. $1 / 8$ shaft length, shaft without sutura uncini. Intramallei small, thin, more or less triangular in lateral view. Supramanubria (Figure 5J,K) conical, distal tips pointing towards trophi axis, bases somewhat swollen with dorsal projection and proximal opening opposite to medio-lateral opening of head of manubria. Manubria long, c. 1.5 incus length, rod-shaped, slightly curved, weakly tapering and outcurving distally, bearing ventral sclerite element near midpoint of curvation: the manubrial spur or calcar manubrii (Figure 5A,B: $\mathrm{cm}$ ); head of manubria only weakly enlarged with proximal medio-lateral opening; calcar manubrii (Figure 5L-N: $\mathrm{cm}$ ) a narrow elongated element with slightly expanded distal end, its ventral surface smooth, the dorsal one with shallow irregular groove. Epipharynx consists of two very thin elongated lamellar structures of unclear shape, bearing two to three strongly sclerified projections distally at median margin (e.g., Figure 5D,H,I: e).

Measurements: Total length $(\mathrm{N}=5)$ : $265-285 \mu \mathrm{m}$; toe: $21-24 \mu \mathrm{m}$; trophi $(\mathrm{N}=5)$ : length 37.0-44.0 $\mu \mathrm{m}$ (mean $40.4 \mu \mathrm{m}$ ), ramus 10.0-11.7 $\mu \mathrm{m}$ (mean $11.0 \mu \mathrm{m}$ ), fulcrum 6.8-8.9 $\mu \mathrm{m}$ (mean $7.9 \mu \mathrm{m}$ ), ventral uncinus 8.2-9.7 $\mu \mathrm{m}$ (mean $9.1 \mu \mathrm{m}$ ), dorsal uncinus 6.2-7.6 $\mu \mathrm{m}$ (mean 7.0 $\mu \mathrm{m}$ ), intramalleus 2.9-3.4 $\mu \mathrm{m}$ (mean $3.2 \mu \mathrm{m}$ ), supramanubrium 5.3-6.5 $\mu \mathrm{m}$ (mean $6.0 \mu \mathrm{m}$ ), manubrium 29.0-33.9 $\mu \mathrm{m}$ (mean $31.2 \mu \mathrm{m}$ ), calcar manubrii 6.8-9.2 $\mu \mathrm{m}$ (mean $7.4 \mu \mathrm{m}$ ). 


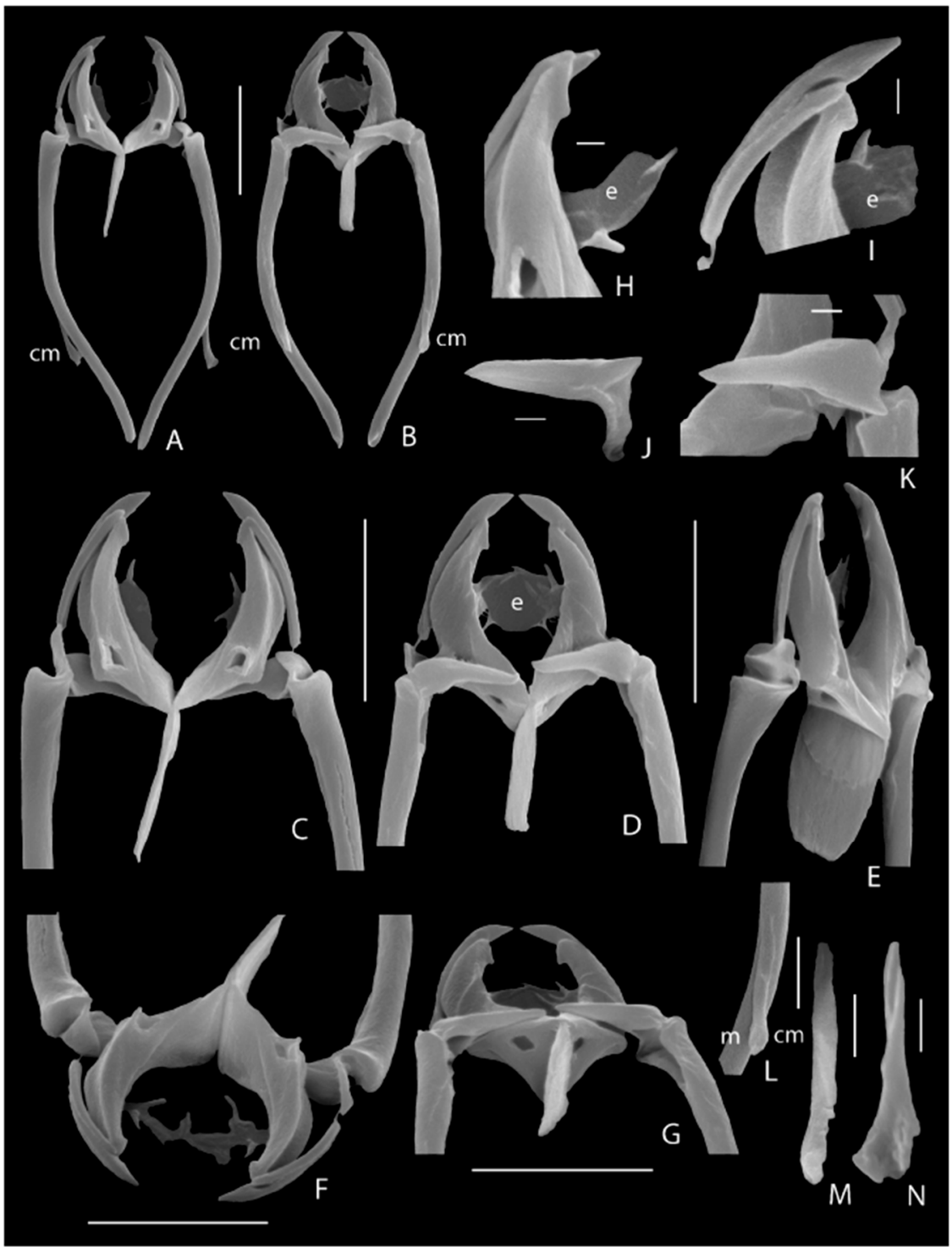

Figure 5. Encentrum rousseleti (Lie-Pettersen, 1905), SEM photographs of trophi. (A) Complete set, dorsal. (B) Complete set, ventral. (C) Detail, dorsal. (D) Detail, ventral. (E) Detail dorso-lateral. (F) Detail, dorso-frontal. (G) Detail, ventro-caudal. (H) Detail left ramus tip and epipharynx, dorsal. (I) As Figure H, dorso-lateral. (J) Right supramanubrium, caudal. (K) Left supramanubrium, ventral. (L,M) Calcar manubrii, ventral. (N) Calcar manubrii, dorsal. ca: caudal antenna; cm: calcar manubrii; e: epipharynx; m: manubrium. Scale bars: (A-G): $10 \mu \mathrm{m} ;(\mathbf{H}-\mathbf{K}): 1 \mu \mathrm{m},(\mathbf{L}): 5 \mu \mathrm{m} ;(\mathbf{M}, \mathbf{N}): 2 \mu \mathrm{m}$.

Comments: Encentrum rousseleti cannot be classified into one of the subgenera of the genus [50,80]. Its close relative is apparently Encentrum salsum Myers, 1936. However, the latter has been insufficiently described, and due to confusion with Myer's E. salsum and E. rousseleti specimens in the collection of the Academy of Natural Sciences of Drexel University, as well as by the condition of the slide and specimen position of the type material of E. salsum in the collection of the American Museum of Natural History (C. Jersabek pers. comm.), the value of the discriminating features needs to be taken with caution. Currently, E. rousseleti is distinguished from E. salsum by a different shape of the toes and a higher number of vitellary nuclei (16-34) versus 4(?) in E. salsum. A detailed description of the trophi of E. salsum is lacking, but from the photograph of the trophi preparation (ANSP 740) attributed to the species (see $[3,83]$ ), it looks that calcares manubriorum and lamellar epipharynges bearing strongly sclerified projections may be present. Both structures, in combination with the absence of preuncinal teeth and unci composed of two distinct uncini, distinguish E. rousseleti (and E. salsum) from 
the congeners studied in detail. Calcares manubriorum were not described formerly in E. rousseleti but only indicated by Remane ([13]: Figure 162B) as small semi-circular structures in his trophi picture. To date, such calcares have not been reported in any other monogonont rotifer.

Encentrum rousseleti is a strictly haline, benthic-periphytic, and interstitial species known from marine coastal habitats, estuaries, and inland saline waters $[6,50,84]$. Salinities at which the species is found range from $10 \%$ o to $34 \%$. It has been reported at several occasions from the Palaearctic region (Europe, Japan), and was once mentioned from U.S.A., New Jersey [3] and Puerto Rico [85].

Class EUROTATORIA De Ridder, 1957

Subclass MONOGONONTA Plate, 1889

Order PLOIMA Hudson and Gosse, 1886

Family Synchaetidae Hudson and Gosse, 1886

Genus Synchaeta Ehrenberg, 1832

Synchaeta grossa De Smet and Leasi, new species

Diagnosis: Medium-sized Synchaeta up to $250 \mu \mathrm{m}$; body plump, vase-shaped; auricles small to medium; foot medium, stout; ventral sensory pit/caudal antenna at some distance from base of toes; toes double, equal, small, bulbous; pseuduncinal plate with comb of five to six lamellar teeth; fimbriae pseuduncinal sinus and fimbriae ramus fibrillary.

Type locality: New Jersey, Barnegat Bay, flat marshes, 39,790567 N, 74,117133 E; site 102, collected 30 March 2012, salinity $=30 \%$.

Material examined: Several females collected from saline marshes located in New Jersey, Maine, and Massachusetts.

Holotype: An adult female in a permanent glycerin glass slide mount deposited in the Royal Belgian Institute of Natural Sciences (R.B.I.N.S.), Brussels, Belgium, IG. 34112, RIR. 285.

Paratypes: Two adult females from type locality in R.B.I.N.S (IG. 34112, RIR. 286), and XX in the Department of Biology, University of Antwerp; 10 stubs each with trophi preparation for SEM in the Department of Biology, University of Antwerp.

Additional material: Several specimens from New Jersey (sites 100, 102-104, 125), Maine (site 140), and Massachusetts (site 143)

Etymology: The Latin grossa, plump, fat, is an adjective referring to the habitus of the species. http://zoobank.org:act:F32F381B-11C6-42E8-B8F3-C757DAFE3BCC.

Description of female: Body plump (Figure 6A,B), in dorsal view vase-shaped, more or less strongly constricted behind head, in lateral view appearing less constricted, constriction with several delicate transversal wrinkles. Trunk ovate in dorsal view, with greatest width near its transversal midline, tapering to short tubular end with varying number (1-3) of transversal rows of very small and narrow U-shaped marks (Figure 6E); in lateral view ventral margin weakly arched, dorsal margin strongly arched and somewhat bulging in posterior half; lateral antennae near posterior fourth of trunk. Head tilted ventrally; auricles rather small to medium; apical field of corona in dorsal view fairly convex, in lateral view apical field strongly convex; apical field with central undivided row of cilia; the four styli characteristic of the genus absent, instead four tufts of sensory setae; dorso-lateral part of corona two prominent ciliated arches, ventral part less prominent; dorsal antenna short. Eyespot(s) absent. Foot medium, stout, slightly pointing ventral, flexible, in dorsal view (Figure 6 C,D) varying from elongate conical (with in its most extended state showing weak lateral expansions near its base), to shorter conical and contracted near its base (integument of this basal zone of varying width weakly cuticularized); in lateral view (Figure 6E) with straight ventral margin and weakly arched dorsal margin; apparently a single pseudosegment, but often very delicate transversal folds near midlength and posterior third; a distinct round ventral sensory pit/caudal antenna(?) distally at some distance from base of toes. Two equal small bulbous toes, with long tip and minute offset tubulus. Pedal glands large, foot length or extending into trunk, with very large reservoirs in distal half. Proventriculus present. Gastric glands large, stalks absent. Vitellarium weakly lobed, eight large spheroid nuclei. 

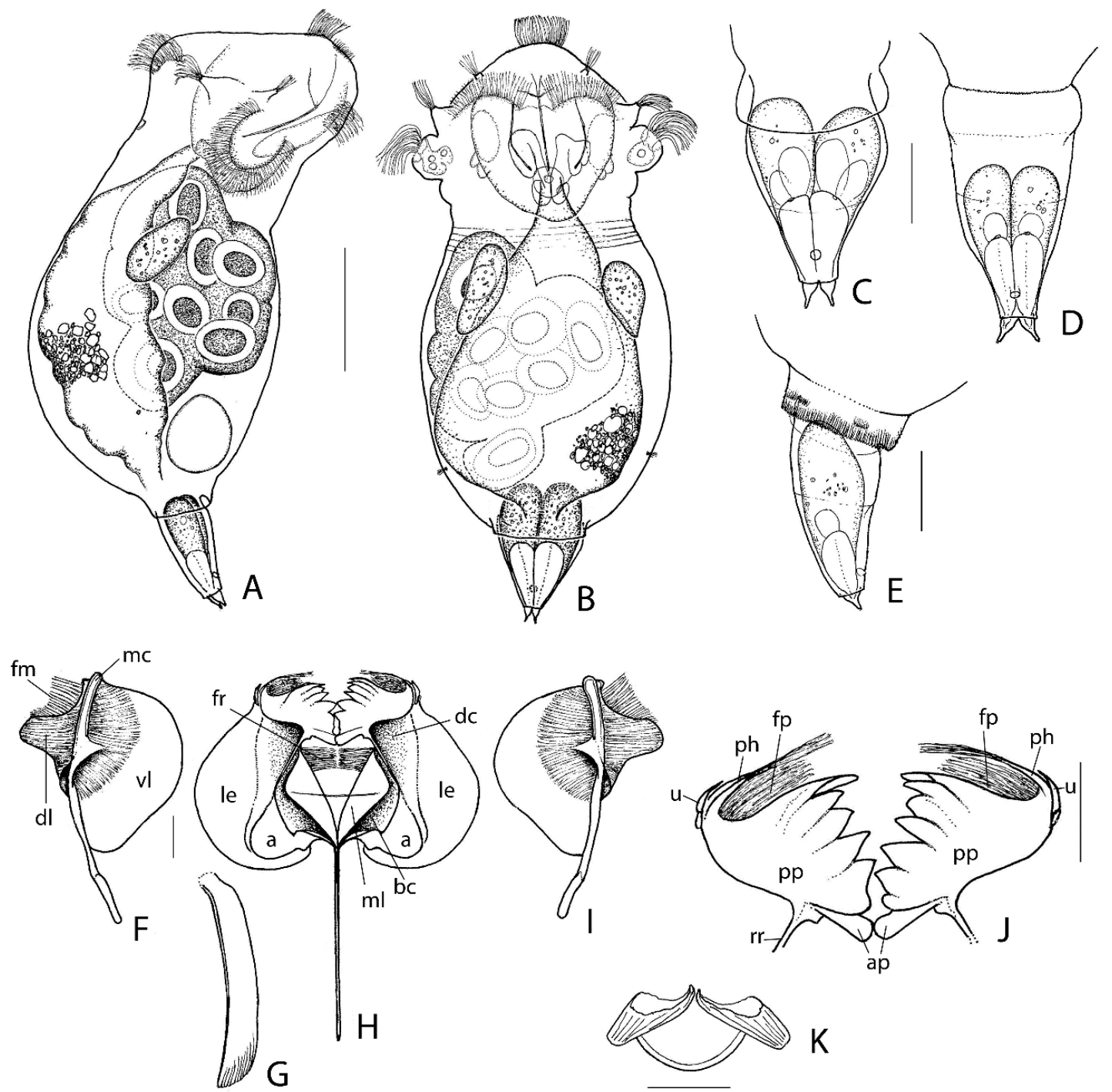

Figure 6. Synchaeta grossa sp. nov., (A) Female, lateral. (B) Female, dorsal. (C) Foot, slightly contracted, dorsal. (D) Foot, extended, ventral. (E) Foot, extended, lateral right. (F) Manubrium, left, outer view. (G) Fulcrum, lateral left. (H) Incus, ventral. (I) Manubrium, right, outer view. (J) Pseuduncus, outer view. (K) Epipharynx, ventral. a: alula; ap: adjoining platelets; bc: basal ramus chamber; dc: dorsal ramus chamber; $\mathrm{dl}$ : dorsal ramus lamella; fm: fimbriae manubrii; fp: fimbriae pseudunci; fr: fimbriae rami; mc: median manubrium chamber; ml: median ramus lamella; le: lamellar ramus extension; ph: pseuduncinal hook; pp: pseuduncinal plate; rr: ramus ridge; u: uncus; vl: ventral lamella. Scale bars: (A,B): $50 \mu \mathrm{m}$; (C-E): $20 \mu \mathrm{m}$; (F-K): $10 \mu \mathrm{m}$.

Amictic egg spherical, smooth.

Trophi (Figure 6F-K and Figure 7) typical Synchaeta, medium sclerified. Rami with ventral basal chamber (Figure 6H, Figure 7D: bc) and dorsal chamber (Figures 6H and 7D: dc) separated by strong ramus ridge (Figures 6J and 7D,E: rr); dorsal chambers with well-developed lamellar extension (Figures 6H and 7A,D: le); large rounded alulae (Figures 6H and 7D,I: a); median margin of basal chambers bearing median rami lamellae (Figures $6 \mathrm{H}$ and 7A,D: $\mathrm{ml}$ ) showing obliquely rounded distal end; basal chambers with medium large latero-caudal spinula rami (Figure 7I: sr); ramus-ramus ligament (Figure 7D,E: rl) inserted slightly above mid-length of median rami lamellae; fimbriae ramorum (Figures 6H and 7J: fr) many separate sclerofibrillae. Epipharynx (Figures 6K and 7C,D: e) composed of two thorn-shaped elements connected distally by their tips in an inverted V-shaped way, and interconnected proximally by a rounded lamella with slightly reinforced free margin; body 
of thorn-shaped elements hollow, showing large anterior opening; bases of thorn-shaped elements connected to ramus ridges (Figure 7D: e). Pseuduncus (Figures 6J and 7E), the ramus ("unci") teeth of Wilke et al. [86], composed of hook, sinus, plate, and adjoining platelet. Pseuduncinal hook (Figures 6J and 7E-G: ph) well developed, gutter-shaped dorsally with free sclerofibrillae emerging at its tip. Sinus between hook and plate with fimbriae pseudunci organised as close-set separate sclerofibrillae (Figures 6J and 7F,G: fp). Pseuduncinal plate (Figures 6J and 7D,E: pp) with comb of five (right) or six (left) lamellar slightly acute similar teeth, each comb terminating in a shallow rounded ventral tooth; teeth more or less gradually decreasing in length towards ventral; incisions between teeth medium without pronounced gap(s); adjoining platelet (Figures $6 \mathrm{~J}$ and $7 \mathrm{E}, \mathrm{H}, \mathrm{J}$ : ap) more or less trapezoid with expanded base and an inner basal comb of sclerofibrillae; ramus ridge at base of pseuduncus with shallow small triangular projection medially. Uncus (Figures 6J and 7E,G: $\mathrm{u}$ ) a single, weakly curved uncinus with slender acute tip; ventral at its base, often a short blunt sclerite (second vestigial uncinus?). Fulcrum thin, long, slightly longer than rami, in lateral view (Figures 6G and 7A) almost parallel-sided; distal end very weakly recurved ventrally, obliquely rounded, without dorsal distal indentation; composed of double layer of sclerofibrillae; ventral margin more or less strongly sclerified, proximal half of dorsal margin weakly sclerified. Manubria (Figure 6F,I and Figure 7B) long, c. 2/3 incus length, weakly curved near mid-length; median chamber (Figures $6 \mathrm{~F}$ and $7 \mathrm{~B}, \mathrm{~K}: \mathrm{mc}$ ) elongated, narrow, continuing as distal cauda; ventral chamber with large semi-circular lamella (Figures $6 \mathrm{~F}$ and 7B: vl) extending from proximal end of median chamber till distal $1 / 4$ of cauda, showing fairly pronounced more strongly sclerified concentric central area; perpendicular line of ventral lamella to median chamber at c. 2/6 from proximal end of the latter; opening of ventral chamber (Figure 7B,K: ov) at c. $1 / 3$ from proximal manubrial end; dorsal chamber with medium large lamella (Figures $6 \mathrm{~F}$ and $7 \mathrm{~B}, \mathrm{~K}: \mathrm{dl}$ ); central part of dorsal lamella tongue-shaped flanked by very shallow proximal extension and less shallow distal tail, margin of top of lamella weakly oblique; perpendicular line of dorsal lamella at c. 1/5 from proximal manubrial end; opening of dorsal chamber (Figure 7B,K: od) at distal end of lamella; distal end of cauda weakly swollen, offset by weak torsion; fimbriae manubrii (Figures $6 \mathrm{~F}$ and $7 \mathrm{~K}: \mathrm{fm}$ ) composed of $c$. 40-45 tiny close-set scleropili; scleropili on shallow proximal extension longest, weakly increasing in length proximally; scleropili on the anterior margin of tongue-shaped part smallest, decreasing in length towards top of lamella.

Measurements: Total length up to $256 \mu \mathrm{m}$, foot ( $\mathrm{N}=5$, extended): $44-60 \mu \mathrm{m}$, toe $(\mathrm{N}=13): 6-9 \mu \mathrm{m}$; trophi $(\mathrm{N}=10)$ length: $80.0-87.4 \mu \mathrm{m}$ (mean $84.2 \mu \mathrm{m}$ ), ramus (inclusive pseuduncus) $34.4-48.3 \mu \mathrm{m}$ (mean $39.2 \mu \mathrm{m}$ ), fulcrum 42.9-51.7 $\mu \mathrm{m}$ (mean $48.0 \mu \mathrm{m}$ ), pseuduncus $(\mathrm{w} \times \mathrm{h})$ 19.6-23.4 $\times 12.4-14.7 \mu \mathrm{m}$ (mean $21.1 \times 13.4 \mu \mathrm{m}$ ), uncus 4.4-5.5 $\mu \mathrm{m}$ (mean $5.0 \mu \mathrm{m}$ ), manubrium 53.9-62.9 $\mu \mathrm{m}$ (mean $56.7 \mu \mathrm{m})$, epipharynx $(\mathrm{w} \times \mathrm{h})$ 10.7-7.8 $\times 23.0-20.8 \mu \mathrm{m}$. Amictic egg $(\mathrm{N}=5): 67-82 \times 67-78 \mu \mathrm{m}$ (mean $70 \times 75 \mu \mathrm{m})$.

Distribution and ecology: Synchaeta grossa sp. nov. was present in samples from New Jersey, Maine, and Massachusetts. It was found exclusively in samples collected from marshes. Samples were collected in March, June, and September at salinities ranging from 10\%o to 34\%o. Examination of the gut content showed that the species feeds on small cocciform Cyanobacteria and fungal spore-rich detritus.

Comments: There is a lot of disagreement on the number of valid species in Synchaeta, which varies from 34 [86], over 37 with 9 more species inquirendae and insufficiently described ones [87], to 41 and 10 species inquirendae [53]. These numbers have to be questioned, as diagnosis and identification rely traditionally on external morphological characters, of which many appear variable or at least difficult to ascertain. Due to this issue, it appears impossible to determine the next related species to S. grossa sp. nov. Most of the information on the delicate trophi of the Synchaeta species is based on light microscopy and, as such, is incomplete or unreliable and highly useless for strict species discrimination. The very few published SEM studies of the trophi and own unpublished data do not allow for a thorough comparison with the new Synchaeta. 


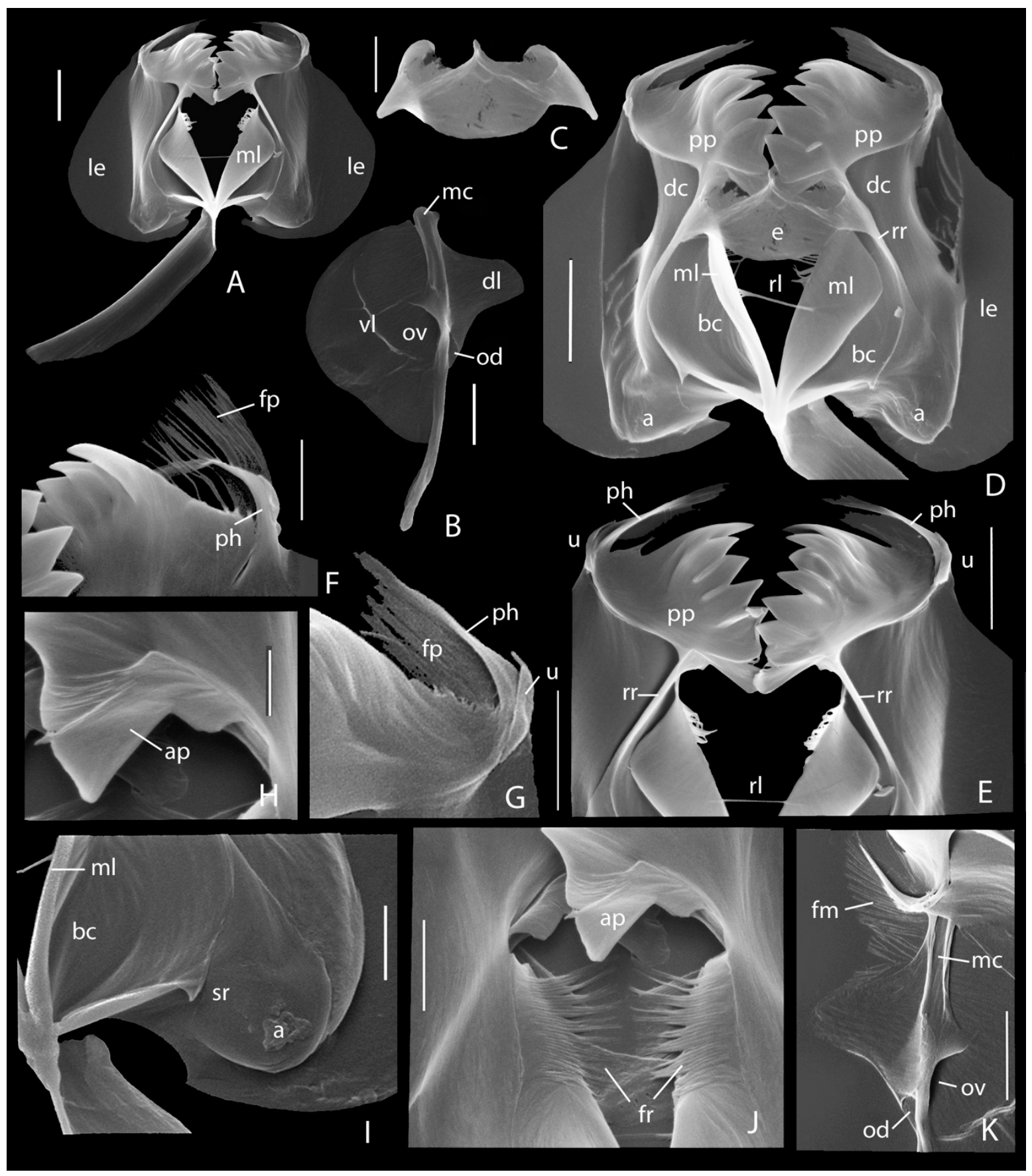

Figure 7. Synchaeta grossa sp. nov., SEM photographs of trophi. (A) Incus, ventral. (B) Left manubrium, outer view. (C) Epipharynx. (D) Detail incus, ventral. (E) Pseudunci, ventral. (F) Detail right pseuduncus, inner view. (G) Detail left pseuduncus, outer view. (H) Adjoining platelet of pseuduncus plate, inner view. (I) Left alula and spinula rami, outer view. (J) Fimbriae ramorum, dorsal. (K) Fimbriae manubrii, outer view, right. a: alula; ap: adjoining platelet; bc: basal chamber; dc: dorsal chamber; dl: dorsal lamella; e: epipharynx; fm: fimbriae manubrii; fp: fimbriae pseudunci; fr: fimbriae rami; mc: median chamber; ml: median ramus lamella; le: lamellar ramus extension; od: opening dorsal chamber; ov: opening ventral chamber; ph: pseuduncinal hook; pp: pseuduncinal plate; rl: ramus-ramus ligament; rr: ramus ridge; sr: spinula rami; u: uncus; vl: ventral lamella. Scale bars: $(\mathbf{A}, \mathbf{B}, \mathbf{D}, \mathbf{E}): 10 \mu \mathrm{m}$; $(\mathbf{C , F}, \mathrm{G}, \mathbf{I}-\mathbf{K}): 5 \mu \mathrm{m},(\mathbf{H}): 2.5 \mu \mathrm{m}$.

The most characteristic features of the S. grossa sp. nov. concern the medium-sized typical foot with its large pedal glands provided with large reservoirs, and the small ventral round opening 
at its distal end some distance anterior to the bases of toes. Such a small opening has never been reported in Synchaeta and is reminiscent of a sensory pit, to date only demonstrated in Lepadellidae and Cotylegaleatidae [88]. However, in the latter families this pit is always located on the dorsal side of the foot. Alternatively, this ventral structure could be a modified and proximally displaced caudal antenna. In Synchaeta baltica Ehrenberg, 1834, S. grimpei Remane, 1929, S. tavina Althaus, 1957, and S. triophthalma Lauterborn, 1894, Peters [89] observed the caudal antenna to be situated ventrally, near or between the bases of the toes, contrasting with the other monogononts, which always show a dorsal caudal antenna [90].

\subsection{Species Composition}

In total, we identified 44 taxa across the 27 sites studied (Table 2): two of those were identifiable bdelloids (Philodina citrina Ehrenberg, 1830 and Rotaria rotatoria (Pallas, 1766)) and 41 belonged to the monogononts. A few specimens identified as bdelloids were too contracted after fixation to allow an accurate diagnostic analysis and are classified as "Bdelloidea indet." in Table 2 and Supplementary Table S1. The monogonont species were distributed over 21 genera and 14 families; 33 of them could be identified to species level, four monogonont species did not match any of the species already described and represented new species for science. Two of these new species were collected in good condition and sufficient numbers, allowing for their description presented above.

Table 2. Rotifer taxa collected at the different sampling sites ${ }^{1}$. Numbers refer to the sampling sites (Table 1).

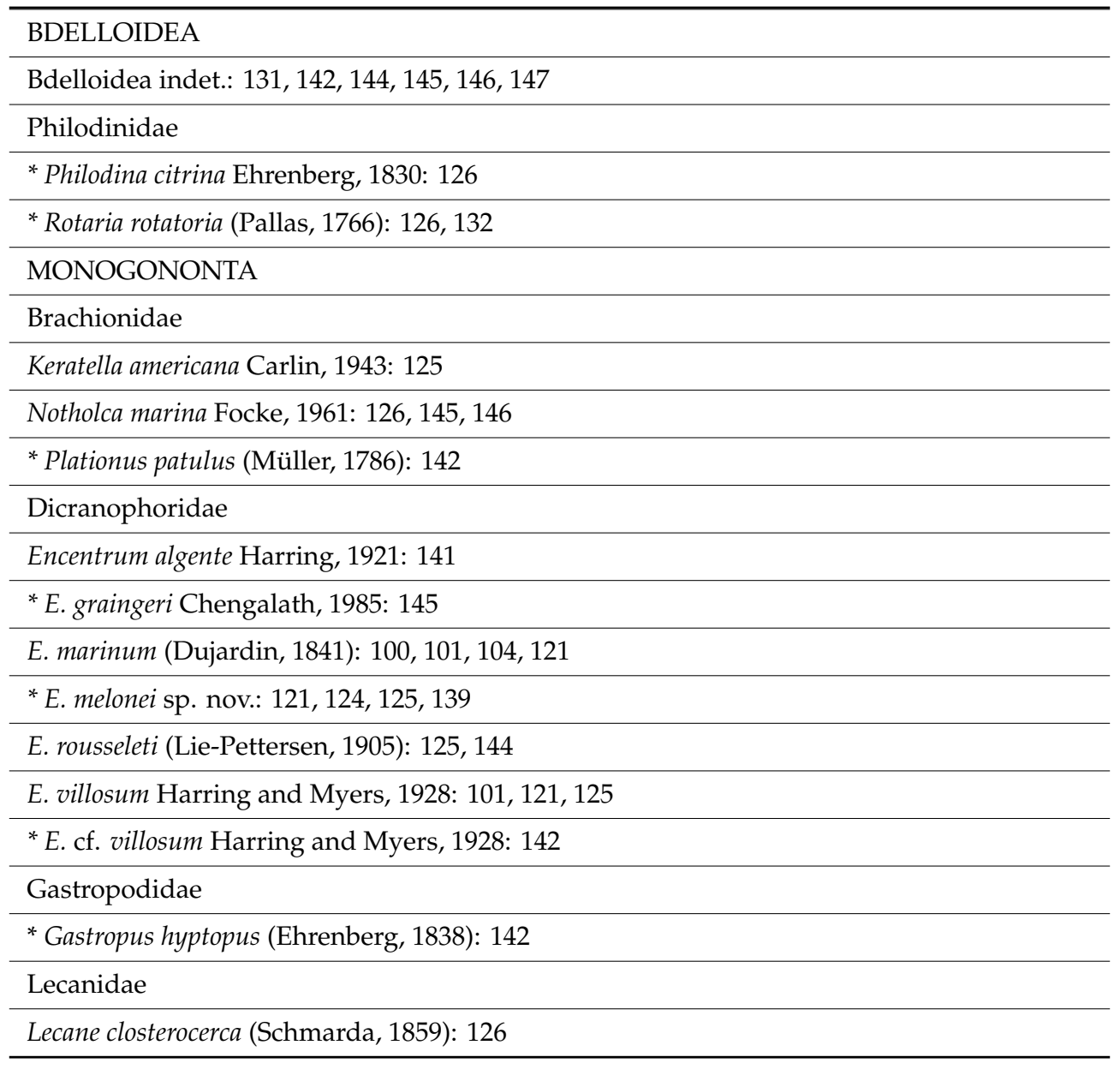


Table 2. Cont.

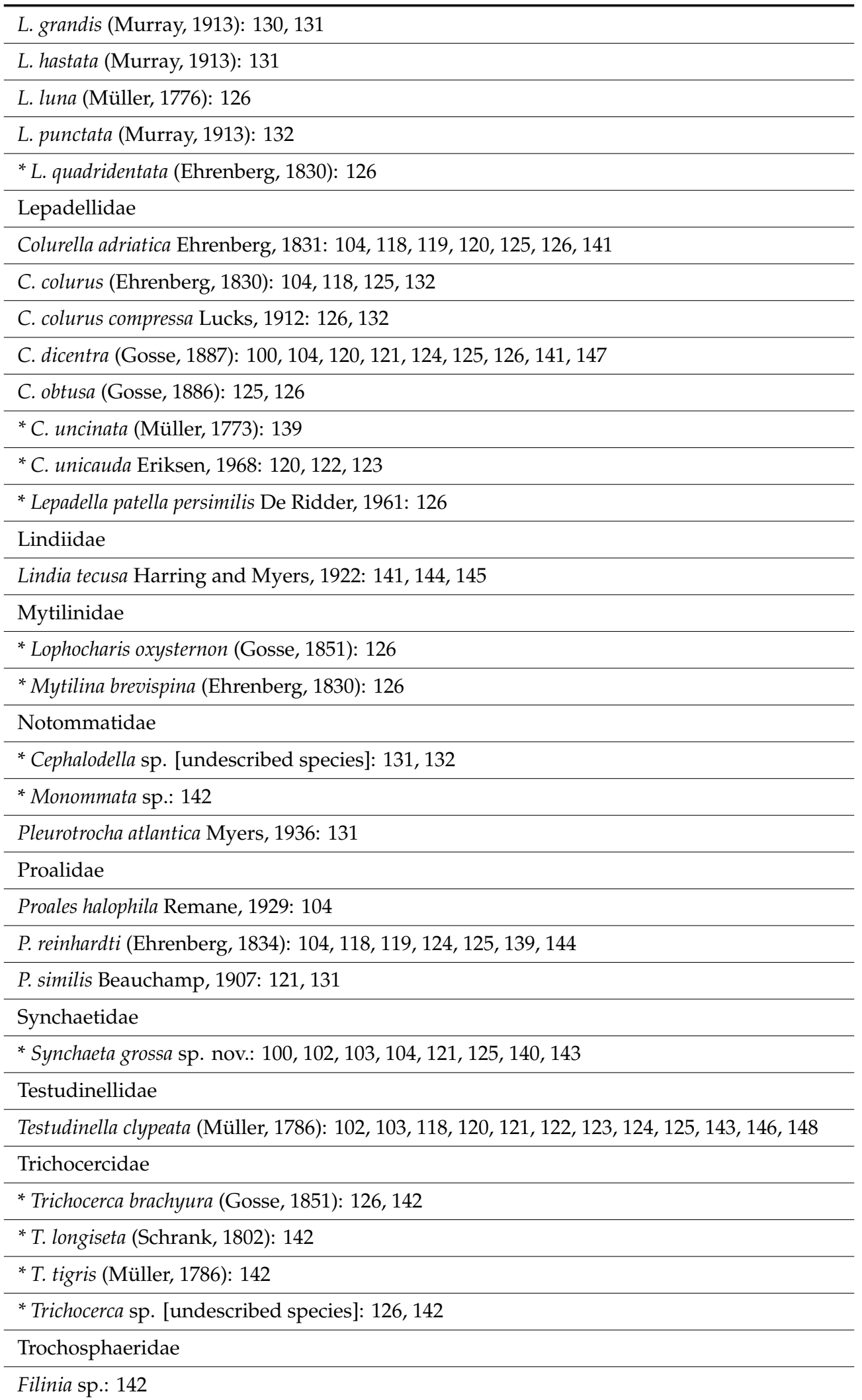

* new for the thalassic fauna of the U.S.A; ${ }^{1}$ Nomenclature according to the proposal of Segers et al. [52] and Jersabek et al. [53]. 
A total of 32 taxa were recorded from the brackish environment, whereas 23 were recorded from the marine sites. Species richness for each sample ( $\alpha$-diversity) ranged from 1 to 15 (mean 5.1) for the brackish environment, and from 1 to 11 (mean 3.7) for the marine habitat. Most of the samples (59\%) had between two and four species. The site with the highest richness (15 species) was the brackish backshore pool from California (site 126; $\mathrm{S}=4 \%$ ). The sites with the lowest richness (one species) were in the brackish marsh from Maine (site 140; $\mathrm{S}=20 \%$ o) and two additional marine sites $(\mathrm{S}=30 \%$ o) from New York (site 130; pond) and Connecticut (site 148; pond). None of the taxa were recorded in all samples, and the majority of them were only found once (21 taxa) or twice (eight taxa).

Bdelloids were found at eight sites: once in a truly marine habitat (New York, site 131; coast, $\mathrm{S}=32 \%$ o) and seven times in brackish habitats with salinities ranging from $2 \%$ o to $10 \%$. As mentioned above, their diversity was low and the only two identifiable species, Philodina citrina and Rotaria rotatoria, were found in the brackish environment $(S=4-8 \%$ o).

Monogononts (41 taxa) were found at all 27 sites and occurred in the whole range of salinities measured during this study $(S=2-40 \%$ o). The most common species across samples was Testudinella clypeata (Müller, 1786), which was found at 12 sites, both brackish and marine (salinity ranging between $6 \%$ and 34\%o), across three states (New Jersey, New Hampshire, Connecticut), and different habitats, such as coastal beaches, channels, lagoons, ponds, and marshes (Table 1 and Supplementary Table S1). The other most frequently occurring species were Colurella dicentra (Gosse, 1887) (nine sites), C. adriatica Ehrenberg, 1831 (seven sites), and Proales reinhardti (Ehrenberg, 1834) (seven sites). The most speciose genera were Encentrum and Colurella, both containing seven species, followed by Lecane, with six species. The most frequently encountered genus was Colurella, occurring at 15 sites.

Most of the taxa identified to species level were common cosmopolites or showed a widespread distribution. A few have a more restricted range: Encentrum rousseleti is known from the Holarctic and Neotropical region; E. villosum Harring and Myers, 1928, Lindia tecusa Harring and Myers, 1922, Notholca marina Focke, 1961, and Pleurotrocha atlantica Myers, 1936 have only been reported from the Holarctic, and the finding of Colurella unicauda Eriksen, 1968, hitherto only known from the Palearctic, is a new record for the Nearctic region. The new species, Encentrum melonei sp. nov. and Synchaeta grossa sp. nov., have at least a Cold Temperate Northwest Atlantic distribution.

\subsection{Community Ecology}

The results of the PERMANOVA analyses showed significant differences in the whole community structures across different salinity values $(p=0.041)$ and ecosystems $(p=0.003)$, as well as in the interaction of the two variables $(p=0.027)$. Nevertheless, the type of ecosystem was a significant predictor of salinity ( $p=0.042$; Figure 8$)$. The highest richness was found in the polyhaline waters (28 species; 12 samples), followed by oligohaline (22 species; 4 samples), euhaline (20 species; 8 samples), and mesohaline (11 species; 4 samples). Circumscribed ponds were the ecosystems with the highest richness (28 species; 7 samples), followed by marshes (18 species; 12 samples), and coasts and environments connected to the ocean (11 species; 8 samples).

Using ordination techniques that combined taxon richness and community composition, we found that rotifer community structures from different salinities or ecosystems partially overlapped (Figure 9); however, all the rotifer communities were significantly different across ecosystems (coast versus marsh, $p=0.021$; coast versus pond, $p=0.037$; marsh versus pond, $p=0.037$ ). Moreover, oligohaline communities, present in salinities lower than $5 \%$, were found to be the most dissimilar to other communities collected at higher salinity. In detail, oligohaline communities were found to be significantly different than both euhaline $(p=0.015)$ and polyhaline communities $(p=0.015)$. 


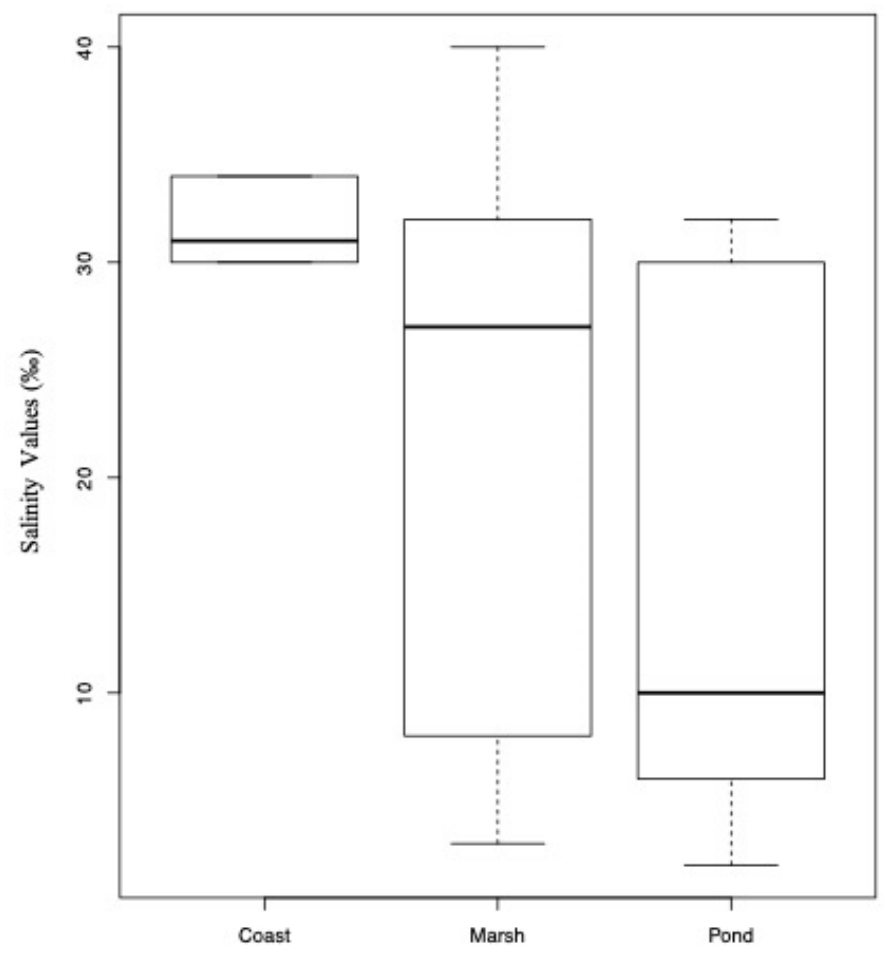

Figure 8. Boxplot showing salinity ranges for each ecosystem. The type of ecosystem was a significant predictor of salinity $(p=0.042)$.
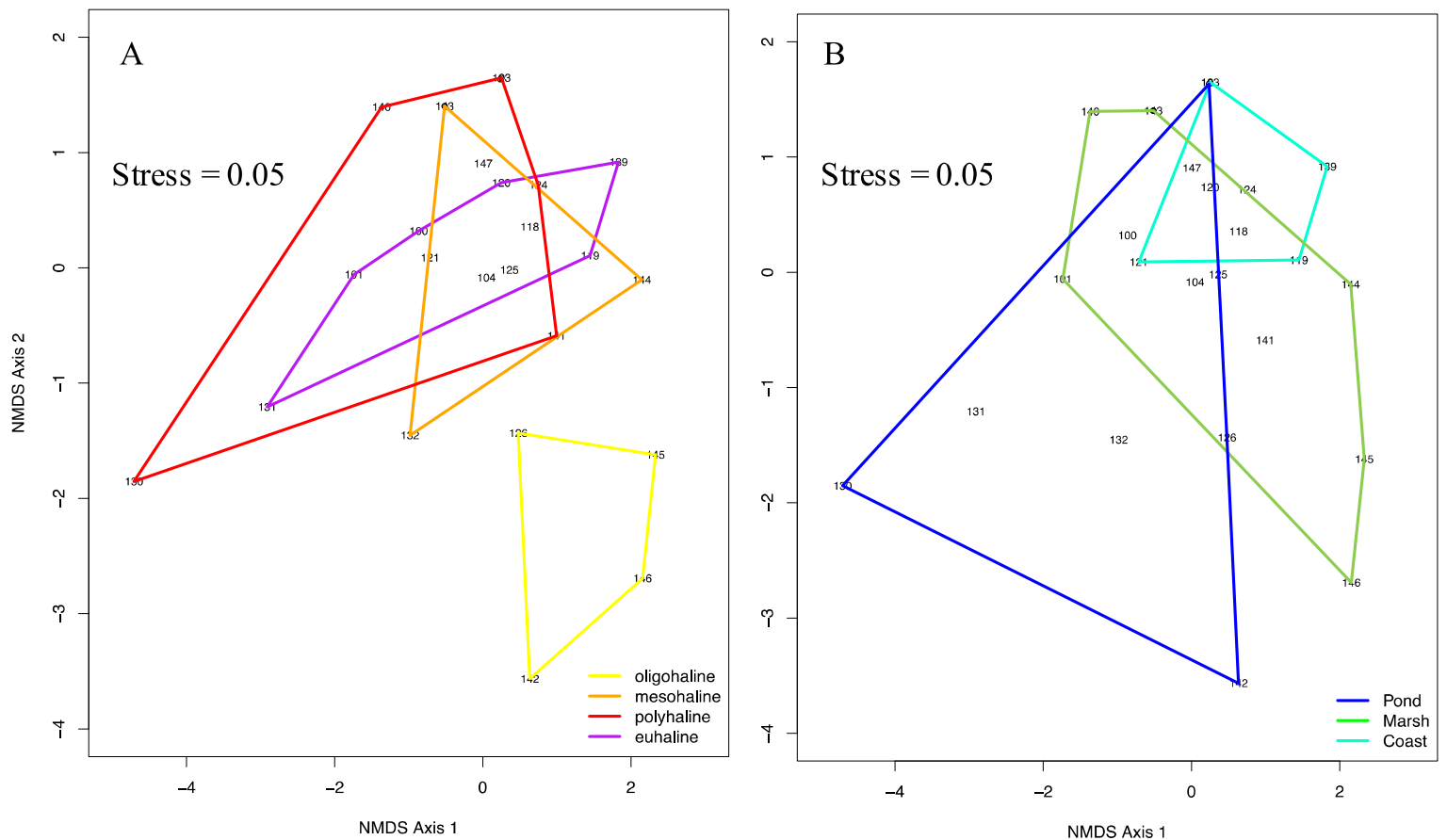

Figure 9. Two-dimensional nonmetric MDS ordination of rotifer community data from 27 sites sampled in the present study. Sites are grouped by salinities according to the Venice System (A) and ecosystems $(\mathbf{B})$.

Results from linear regression analyses showed that, in our study, sample size (number of samples collected from each ecosystem or salinity) was not correlated with biodiversity, estimated as both species richness and species composition $(p>0.1)$. 


\subsection{Thalassic Rotifer Taxa from the U.S.}

The checklist and distribution of rotifer taxa reported to date from the United States are presented in alphabetical order in Supplementary Text S1 and organized per family in Supplementary Table S1. Our search of more than a century of literature [3,18-41,59-79] for thalassic rotifers of the U.S. revealed 105 taxa, among which were 87 species-level taxa. The 44 taxa recorded in the present study and two additional unpublished records add 24 new taxa to this list, of which 19 are fully identified species (inclusive of the two described new species). This brings the total richness of thalassic rotifer taxa reported for the U.S. to at least 124, of which 106 are species-level taxa. Seisonacea is represented by a single species, Paraseison kisfaludyi Leasi, Rouse, Sørensen 2011; only two Bdelloidea, Philodina citrina and Rotaria rotatoria, belonging to the family Philodinidae, were identified to species level. The Monogononta form the most represented group, including 103 (98\%) species-level taxa, distributed over 17 families and 30 genera; another two taxa were reported at the genus level solely (Asplanchna, Monommata). The most speciose families are Brachionidae (18 species, 5 genera), followed by Synchaetidae (15 species, 3 genera), Dicranophoridae (14 species, 3 genera), Lecanidae (10 species, 1 genus), and Lepadellidae (9 species, 2 genera).

\subsection{Distribution of U.S. Thalassic Rotifers}

It follows from Supplementary Table S1 that our knowledge on the distribution of U.S. thalassic rotifers is very incomplete and limited to only a few relatively small areas. Therefore, in the tabulation of the data, we used the system by Fautin et al. [15], which broadly recognizes six geographically-based sections (Northeast U.S. Continental Shelf Large Marine Ecosystem (LME), Southeast U.S. Continental Shelf LME, Gulf of Mexico, Insular-Pacific Hawaii LME, California Current LME, and High Arctic), instead of Spalding et al. [91], who proposed a detailed marine biogeography system including Realms, Provinces, and Ecoregions. Most of the research and occasional records on thalassic rotifers are focused in the Northeast U.S. (93 taxa), followed by the Gulf of Mexico (43 taxa), California Current (26 taxa), Southeast U.S. Continental Shelf (3 taxa), Insular-Pacific Hawaii (6 taxa), and High Arctic (9 taxa). Although the majority (about $90 \%$ ) of the species are believed to be cosmopolitan or widely distributed, none of them are reported from all the U.S. marine biogeographical sections. Eleven species are, to date, only known from their type locality or from a limited number of U.S. locations: Cephalodella epitedia Myers, 1924 (New Jersey), C. mineri Myers, 1924 (New Jersey), Encentrum eristes Harring and Myers, 1928 (Maine), E. lacidum Harring and Myers, 1928 (New Jersey, Maine), E. melonei sp. nov. (New Jersey, Maine), E. salsum Myers, 1936 (New Jersey), Ptygura agassizi Edmondson, 1948 (Massachusetts), Synchaeta grossa sp. nov. (New Jersey, Maine, Massachusetts), S. johanseni Harring, 1921 (New Jersey, Maine), Testudinella dentata Myers, 1934 (New Jersey, Maine), and Paraseison kisfaludyi (California). The only species characteristic for a well-defined section or ecoregion, namely the High Arctic, are Synchaeta hyperborea Smirnov, 1932 and S. tamara Smirnov, 1932 found in Alaska (Bering and Beaufort Seas), and known as typical inhabitants of marine plankton from the Arctic Ocean and Arctic seas, and brine channels of Arctic sea ice [92].

To date, 355 species are known to occur in thalassic environments world-wide, thus, at least about one-third (106 species) of the known global thalassic rotifer diversity is present in U.S. waters. The finding of Trichocerca tigris (Müller, 1786) in oligohaline water, hitherto only known from freshwater, is an extension of it to the saline habitat [6].

\section{Discussion}

The biodiversity of freshwater rotifers is regularly explored: new species are described continuously and environmental interactions are profoundly tested (e.g., $[1-3,93,94])$. In contrast, taxonomic and ecological investigations targeting thalassic rotifers are sporadic (but see $[9-11,43,92,95-97])$. This study allowed us to improve our knowledge of the biodiversity of 
thalassic rotifers in the United States and revealed new correlations between rotifer communities and their environments.

Overall, 106 thalassic rotifer species-level taxa are reported for the United States, representing 30\% of the total number of thalassic rotifer species recognized worldwide. Most of the recorded species are common cosmopolites. A total of 11 species so far are exclusively known for the United States, however, too little information is available to speculate about possible endemisms. The results of our investigation and the data from the checklist show (1) a low thalassic species richness compared to the known freshwater species world-wide (ca. 1830 species, among bdelloids and monogononts), and (2) an obvious predominance of monogonont species (95-98\%) with regard to bdelloids (2-5\%). This concurs with the general observations that the thalassic rotifer fauna is rather poor and that bdelloids are highly underrepresented in thalassic environments $[2,4,6,7,11]$. For example, the work performed by Myers [24] focused on the rotifer diversity from the small Mount Desert Island (280 $\mathrm{km}^{2}$ ) situated on the coast of Maine. He reported 435 freshwater species (and many more were added in subsequent papers) and only 14 marine ones. Almost a century later, only a total of 22 thalassic rotifer taxa are known for the entire State of Maine (Supplementary Table S1). No doubt, besides a real difference in the rotifer diversity between the freshwater and marine environment, these numbers may also be biased by unequal sampling efforts. Regarding the bdelloid/monogonont ratio, in a review of rotifer diversity from saltwater environments, Fontaneto et al. [6] reported the presence of 443 species, and an overall ratio of bdelloid to monogonont species of 1:3 in freshwater habitats and 1:83 in thalassic ones. This ratio is 1:53 for the U.S. thalassic rotifers identified to species level.

In the present research, we found 44 taxa, among which 17 identified at the species level are first records for the U.S. thalassic rotifer fauna, including two species new to science (Encentrum melonei sp. nov., Synchaeta grossa sp. nov.). Two other species new to science were only identified to genus level (Cephalodella, Trichocerca). A half century ago, Björklund [28] described a new species of monogonont rotifer, Notholca liepetterseni Bjorklund, 1972 from the Hudson River mouth (New York). Since then, no new marine rotifer species have been discovered and described for the U.S. until today. Exceptionally, a few years ago a new species of Seisonacea was described for California [38]. However, Seisonacea is an aberrant group of marine rotifers that live as epizoonts on the crustacean genus Nebalia. Hitherto, only four species are known and their discovery is likely due to coincidental circumstances rather than actual sampling efforts focused on this group. The discovery of four monogonont species new to science, two of which are described herein, encourages further investigations on the U.S. marine rotifers. Reporting the presence of additional rotifer species in the U.S. may not be surprising, especially considering the limited number of investigations on thalassic environments. The highest richness (93 taxa, 83 species) is reported for the Northeast Continental Shelf. No doubt this highest richness is a clear case created by bias in sampling intensity, known as the "rotiferologist effect" [12]: indeed, the majority of investigations, as well as the present ones, have been focused on this region. Notwithstanding this rotiferologist effect, the finding of additional 15 taxa and 11 species never reported for the Northeast Continental Shelf reveals that the biodiversity of thalassic rotifers is largely overlooked and underestimated. In particular, the environmental heterogeneity of the Northwest Atlantic coast, characterized by a variety of ecological niches, may play a fundamental role in the diversification of small species. A highly debated and still open issue in ecology is whether the patterns of distribution of biodiversity are caused by spatially limited dispersal or by niche-related factors [98]. Carugati et al. [99] showed that the assemblage structure of meiofauna is mainly shaped by dispersal limitation and habitat features. Older studies rarely indicated the habitat and its features, and it is often even difficult to track down the precise sampling location.

The present study shows that both the salinity and the type of ecosystem, as defined herein, significantly drives species assemblage. The oligohaline environment contained mainly species known to live in freshwater and a few euryhaline species, whereas the euhaline environment was dominated by euhaline and euryhaline species. Previous studies based on DNA taxonomy suggested that rotifer species respond differently to salinity. Some taxa seem ecologically specialized to narrow salinity 
ranges (e.g., Brachionus plicatilis Müller, 1786: [100]), while other species occurring at different salinities are likely ecologically tolerant (e.g., Testudinella clypeata: [43]). The response of an organism to an environmental condition mainly depends on its eco/evolutionary origin (e.g., [101-104]). However, the evolutionary origins of most small organisms are still unknown and should be clarified by further phylogenetic studies. Not surprisingly, the type of ecosystem resulted significantly correlated with the salinity values; inevitably, rotifer species were differently distributed also across all the three ecosystems, besides salinities. This suggests that each ecosystem hosts a peculiar rotifer community and certain environments, such as salt marshes, may represent a hotspot of biodiversity also for microscopic species $[105,106]$. A comprehensive understanding of such unstable environments is critical, given their unique dynamics and susceptibility to anthropogenic stressors [106].

The United States is affected by numerous anthropogenic activities occurring in salt waters, such as oil drilling, fisheries, and tourism. As such, the territory is significantly impacted, and delicate and valuable ecosystems, such as salt marshes and beaches, could be quickly and irremediably endangered. Because small species respond quickly to environmental changes due to their rapid life cycle, they can be used also to determine the impact of habitat loss and modification due to human activities. Moreover, salinization plays a fundamental role under a climate change scenario and investigating the biodiversity of small species will provide fundamental information for long-term ecosystem biomonitoring programs [107]. As suggested by Zeppilli et al. [108], this work supports the value of investigating the biodiversity of small invertebrates as ideal models to evaluate and understand the either short- or long-term effects of human activities on the surrounding environments.

Supplementary Materials: The following are available online at http://www.mdpi.com/1424-2818/12/1/28/s1. Text S1. Annotated checklist of rotifer taxa reported from thalassic environments in the U.S.A; Table S1: Distribution of rotifers found in thalassic environments of the U.S.A. The table includes the list of taxa (first column); biogeographical areas according to Fautin et al. [15] (Northeast U.S. Continental Shelf Large Marine Ecosystem, Southeast U.S. Continental Shelf LME, Gulf of Mexico, Insular-Pacific Hawaii LME, California Current LME, and High Arctic); and U.S. States within each area (CA, California; CT, Connecticut; MA, Massachusetts; ME, Maine; NH, New Hampshire; NJ, New Jersey; NY, New York). +, the rotifer taxon has been recorded for that area/state. The table includes the associated list of references, which bibliography is included in the main text.

Author Contributions: Conceptualization, F.L. and W.H.D.S.; methodology, F.L. and W.H.D.S.; formal analysis, F.L.; investigation, F.L. and W.H.D.S.; resources, F.L. and W.H.D.S.; data curation, F.L. and W.H.D.S.; writing-original draft preparation, F.L. and W.H.D.S.; writing-review and editing, F.L. and W.H.D.S.; visualization, F.L. and W.H.D.S.; supervision, F.L. and W.H.D.S.; project administration, F.L. and W.H.D.S.; funding acquisition, F.L. All authors have read and agreed to the published version of the manuscript.

Funding: This work was performed thank to the John J. and Anna H. Gallagher Fellowship granted to FL by the Academy of Natural Sciences of Drexel University, Philadelphia. The Laboratory of Cell Biology and Histology, University of Antwerp, is greatly acknowledged for access to the scanning electron microscope. We thank C. Jersabek for providing photographs and information on the holotype trophi (AMNH 830) and paratype females of E. salsum (AMNH 832). The founding sponsors had no role in the design of the study; in the collection, analyses, or interpretation of data; in the writing of the manuscript, and in the decision to publish the results.

Acknowledgments: We are grateful to B. Kirby for editing an early version of the manuscript and E. Laflamme for his advices regarding the analyses and plots performed in R.

Conflicts of Interest: The authors declare no conflict of interest.

\section{References}

1. Segers, H. Annotated checklist of the rotifers (Phylum Rotifera), with notes on nomenclature, taxonomy and distribution. Zootaxa 2007, 1546, 104. [CrossRef]

2. Segers, H. Global diversity of rotifers (Rotifera) in freshwater. Hydrobiologia 2008, 595, 49-59. [CrossRef]

3. Jersabek, C.D.; Leitner, M.F. The Rotifer World Catalog. World Wide Web Electronic Publication, 2013. Available online: http://www.rotifera.hausdernatur.at/Species/Index/222 (accessed on 15 June 2019).

4. Fontaneto, D.; De Smet, W.H. Rotifera. In Handbook of Zoology: Gastrotricha, Cycloneuralia and Gnathifera. Volume 3: Gastrotricha and Gnathifera; Schmidt-Rhaesa, A., Ed.; Walter de Gruyter: Berlin, Germany, 2015; pp. 217-300. 
5. Wallace, R.L.; Snell, T.W. Chapter 8-Rotifera. In Ecology and Classification of North American Freshwater Invertebrates, 3rd ed.; Thorp, J.H., Covich, A.P., Eds.; Academic Press: San Diego, CA, USA, 2010; pp. 173-235.

6. Fontaneto, D.; De Smet, W.H.; Ricci, C. Rotifers in saltwater environments, re-evaluation of an inconspicuous taxon. J. Mar. Biol. Assoc. U. K. 2006, 86, 623-656. [CrossRef]

7. Fontaneto, D.; De Smet, W.H.; Melone, G. Identification key to the genera of marine rotifers worldwide. Meiofauna Mar. 2008, 16, 75-99.

8. Appeltans, W.; Ahyong, S.T.; Anderson, G.; Angel, M.V.; Artois, T.; Bailly, N.; Bamber, R.; Barber, A.; Bartsch, I.; Berta, A.; et al. The Magnitude of Global Marine Species Diversity. Curr. Biol. 2012, 22, 2189-2202. [CrossRef]

9. Curini-Galletti, M.; Artois, T.; Delogu, V.; De Smet, W.H.; Fontaneto, D.; Jondelius, U.; Leasi, F.; Martínez, A.; Meyer-Wachsmuth, I.; Nilsson, K.S.; et al. Patterns of diversity in soft-bodied meiofauna: Dispersal ability and body size matter. PLOS ONE 2012, 7, e33801. [CrossRef]

10. De Smet, W.H.; Melone, G.; Fontaneto, D.; Leasi, F. Marine Rotifera. In Fauna D'Italia Volume 50; Calderini: Bologna, Italy, 2015; p. 252.

11. Fontaneto, D.; Segers, H.; Melone, G. Marine rotifers from the Northern Adriatic Sea, with description of Lecane insulaconae sp. nov. (Rotifera: Monogononta: Lecanidae). J. Mar. Biol. Assoc. U. K. 2008, 88, 253-258. [CrossRef]

12. Fontaneto, D.; Barbosa, A.M.; Segers, H.; Pautasso, M. The 'rotiferologist' effect and other global correlates of species richness in monogonont rotifers. Ecography 2012, 35, 174-182. [CrossRef]

13. Remane, A. Rotatoria. In Die Tierwelt der Nord- und Ostsee, 16(7.e); Akademische Verlagsgesellschaft M.B.H.: Leipzig, Germany, 1929; p. 156.

14. Dumont, H.J. Biogeography of Rotifers BT-Biology of Rotifers; Pejler, B., Starkweather, R., Nogrady, T., Eds.; Springer: Dordrecht, The Netherlands, 1983; pp. 19-30.

15. Fautin, D.; Dalton, P.; Incze, L.S.; Leong, J.-A.C.; Pautzke, C.; Rosenberg, A.; Sandifer, P.; Sedberry, G.; Tunnell, J.W., Jr.; Abbott, I.; et al. An Overview of Marine Biodiversity in United States Waters. PLoS ONE 2010, 5, e11914. [CrossRef] [PubMed]

16. Miller, W.R.; Perry, E.S. The coastal marine Tardigrada of the Americas. Zootaxa 2016, 4126, 375-396. [CrossRef]

17. Leasi, F.; Sevigny, J.L.; Laflamme, E.M.; Artois, T.; Curini-Galletti, M.; de Jesus Navarrete, A.; Di Domenico, M.; Goetz, F.; Hall, J.A.; Hochberg, R.; et al. Biodiversity estimates and ecological interpretations of meiofaunal communities are biased by the taxonomic approach. Commun. Biol. 2018, 1, 112. [CrossRef] [PubMed]

18. Smith, J.C. Synchaeta bicornis: A new rotifer from the brackish waters of Lake Pontchartrain, Louisiana. Trans. Am. Microsc. Soc. 1904, 25, 121-126. [CrossRef]

19. Harring, H.K. A list of the Rotatoria of Washington and vicinity, with descriptions of a new genus and ten new species. Proc. U. S. Natl. Mus. 1913, 46, 387-405. [CrossRef]

20. Harring, H.K.; Myers, F.J. The rotifer fauna of Wisconsin. Trans. Wis. Acad. Sci. Arts Lett. 1922, $20,553-662$.

21. Harring, H.K.; Myers, F.J. The rotifer fauna of Wisconsin-II. A revision of the notommatid rotifers, exclusive of the Dicranophoridae. Trans. Wis. Acad. Sci. Arts Lett. 1924, 50, 415-549.

22. Harring, H.K.; Myers, F.J. The rotifer fauna of Wisconsin-III. A revision of the genera Lecane and Monostyla. Trans. Wis. Acad. Sci. Arts Lett. 1926, 50, 315-423.

23. Harring, H.K.; Myers, F.J. The rotifer fauna of Wisconsin-IV. The Dicranophoridae. Trans. Wis. Acad. Sci. Arts Lett. 1928, 23, 666-808.

24. Myers, F.J. The distribution of Rotifera on Mount Desert Island. Am. Mus. Novit. 1931, 494, 12.

25. Myers, F.J. The distribution of Rotifera on Mount Desert Island. Part VII. New Testudinellidae of the genus Testudinella and new species of Brachionidae of the genus Trichotria. Am. Mus. Novit. 1934, 761, 8.

26. Myers, F.J. Three new brackish water and one new marine species of Rotatoria. Trans. Am. Microsc. Soc. 1936, 55, 428-432. [CrossRef]

27. Edmondson, W.T. Rotatoria from Penikese Island, Massachusetts, with a description of Ptygura agassizi n. sp. Biol. Bull. 1948, 94, 263-266. [CrossRef] [PubMed]

28. Björklund, B.G. Taxonomic and ecological studies of species of Notholca (Rotatoria) found in sea- and brackish water, with description of a new species. Sarsia 1972, 51, 25-66. [CrossRef]

29. Ahlstrom, E. Rotatoria of Florida. Trans. Am. Microsc. Soc. 1934, 53, 251-266. [CrossRef] 
30. Ahlstrom, E. A revision of the rotatorian genera Brachionus and Platyias with descriptions of one new species and two new varieties. Bull. Am. Mus. Nat. Hist. 1940, 77, 148-184.

31. Koste, W. Das Rädertier-Porträt. Einige auffalende Synchaeta-Arten aus Küstengewässern. Mikrokosmos 1981, 70, 169-176.

32. Turner, P. Distribution of rotifers in a Floridian saltwater beach, with a note on rotifer dispersal. Hydrobiologia 1993, 255, 435-439. [CrossRef]

33. Turner, P.N. Some Interstitial Rotifera from a Florida, U.S.A., Beach. Trans. Am. Microsc. Soc. 1990, 109, 417-421. [CrossRef]

34. Harring, H.K. The Rotatoria of the Canadian Arctic Expedition, 1913-1918. Rep. Can. Arct. Exp. 1921, 8 Pt E, 3-23.

35. Weber, E.F. Rotateurs (Voyage du Dr. W. Volz.). Zool. Jahrb. 1907, 24, 207-226.

36. Hauer, J. Rotatorien aus dem "Zwischengebiet Wallacea". 1. Teil. I. Das Genus Pedalia Barrois. Int. Rev. Der Gesamten Hydrobiol. Und Hydrogr. 1941, 41, 177-203. [CrossRef]

37. Jersabek, C.D. Freshwater Rotifera (Monogononta) from Hawai'i, a preliminary checklist. Bishop Mus. Occas. Pap. 2003, 74, 46-72.

38. Leasi, F.; Rouse, G.W.; Sørensen, M.V. A new species of Paraseison (Rotifera: Seisonacea) from the coast of California, USA. J. Mar. Biol. Assoc. U. K. 2012, 92, 959-965. [CrossRef]

39. Heinbokel, J.; Coats, D.; Henderson, K.; Tyler, M. Reproduction rates and secondary production of three species of the rotifer genus Synchaeta in the estuarine Potomac River. J. Plankton Res. 1988, 10, 659-674. [CrossRef]

40. Dolan, J.; Gallegos, C. Trophic coupling of rotifers, microflagellates, and bacteria during fall months in the Rhode River Estuary. Mar. Ecol. Prog. Ser. 1991, 77, 147-156. [CrossRef]

41. Park, G.S.; Marshall, H.G. The trophic contributions of rotifers in tidal freshwater and estuarine habitats. Estuar. Coast. Shelf Sci. 2000, 51, 729-742. [CrossRef]

42. Ekman, S. Zoogeography of the Sea; Sidgwick \& Jackson Ltd.: London, UK, 1953; p. 417.

43. Leasi, F.; Tang, C.Q.; De Smet, W.H.; Fontaneto, D. Cryptic diversity with wide salinity tolerance in the putative euryhaline Testudinella clypeata (Rotifera, Monogononta). Zool. J. Linn. Soc. 2013, 168, 17-28. [CrossRef]

44. Anonymous. The Venice System for the Classification of Marine Waters According to Salinity. Limnol. Oceanogr. 1958, 3, 346-347.

45. Willems, W.; Curini-Galletti, M.; Ferrero, T.; Fontaneto, D.; Heiner, I.; Huys, R.; Ivanenko, V.N.; Kristensen, R.M.; Kånneby, T.; MacNaughton, M.; et al. Meiofauna of the Koster-area, results from a workshop at the Sven Lovén Centre for Marine Sciences (Tjärnö, Sweden). Meiofauna Mar. 2009, 17, 1-34.

46. Koste, W. Rotatoria. Die Rädertiere Mitteleuropas. Ein Bestimmungswerk, Begründet Von Max Voigt. Ueberordnung Monogononta, 2nd ed.; Tafelband, 234 Taf; Gebr. Borntraeger: Berlin, Germany; Stuttgart, Germany, 1978; p. 673.

47. Nogrady, T.; Pourriot, R.; Segers, H. Rotifera. Volume 3. The Notommatidae and the Scaridiidae. In Guides to the Identification of the Microinvertebrates of the Continental Waters of the World; Nogrady, T., Ed.; SPB Academic Publishing bv: The Hague, The Netherlands, 1995; p. 248.

48. Segers, H. Rotifera, Volumr 2: The Lecanidae (Monogononta). In Guides to the Identification of the Microinvertebrates of the Continental Waters of the World; Nogrady, T., Ed.; SPB Academic Publishing bv: The Hague, The Netherlands, 1995; p. 226.

49. De Smet, W.H. Rotifera. Volume 4. The Proalidae (Monogononta). In Guides to the Identification of the Microinvertebrates of the Continental Waters of the World; Nogrady, T., Ed.; SPB Academic Publishing bv: The Hague, The Netherlands, 1996; p. 102.

50. De Smet, W.H. The Dicranophoridae and the Ituridae (Monogononta). In Guides to the Identification of the Microinvertebrates of the Continental Waters of the World; Nogrady, T., Ed.; SPB Academic Publishing bv: The Hague, The Netherlands, 1997; p. 325.

51. Nogrady, T.; Segers, H. Rotifera. Volume 6. The Asplanchnidae, Gastropodidae, Lindiidae, Microcodinidae, Synchaetidae, Trochosphaeridae and Filinia. In Guides to the Identification of the Microinvertebrates of the Continental Waters of the World; Nogrady, T., Ed.; Backhuys Publishers: Leiden, The Netherlands, 2002; p. 264.

52. Segers, H.; Fisher, W.; Fontaneto, D.; Michaloudi, E.; Wallace, R.L.; Jersabek, C.D. Towards a list of available names in zoology, partim Phylum Rotifera. Zootaxa 2012, 3179, 61-68. [CrossRef] 
53. Jersabek, C.D.; De Smet, W.H.; Hinz, C.; Fontaneto, D.; Michaloudi, E.; Wallace, R.L.; Segers, H. List of Available Names in Zoology, Candidate Part Phylum Rotifera, Species-Group Names Established before 1 January 2000. Final Version. 1 January 2018. Available online: https://www.iczn.org/assets/a42ca743cc/LAN_ CandidatePart-SpeciesRotifera-2018-04-11.pdf (accessed on 13 January 2020).

54. De Smet, W.H. Preparation of rotifer trophi for light and scanning electron microscopy. Hydrobiologia 1998, 387, 117-121. [CrossRef]

55. Oksanen, J.; Blanchet, F.G.; Kindt, R.; Legendre, P.; Minchin, P.R.; O’Hara, R.B.; Simpson, G.L.; Solymos, P.; Stevens, M.H.H.; Wagner, H. Package 'Vegan'. R Package Version 2.0-8. 2013, Volume 254. Available online: https://cran.r-project.org/web/packages/vegan/index.html (accessed on 13 January 2020).

56. Hervé, M. RVAideMemoire: Testing and Plotting Procedures for Biostatistics. R Package Version 0.9-72. 2019. Available online: https://cran.r-project.org/web/packages/RVAideMemoire/RVAideMemoire.pdf. (accessed on 13 January 2020).

57. Faith, D.P.; Minchin, P.R.; Belbin, L. Compositional dissimilarity as a robust measure of ecological distance. Vegetatio 1987, 69, 57-68. [CrossRef]

58. Chambers, J.M.; Freeny, A.E.; Heiberger, R.M. Analysis of variance; designed experiments. In Statistical Models in S; Routledge: New York, NY, USA, 2017; pp. 145-193.

59. Ambler, J.; Cloern, J.; Hutchinson, A. Seasonal cycles of zooplankton from San Francisco Bay. Hydrobiologia 1985, 129, 177-197. [CrossRef]

60. Battaglene, S.; Talbot, B. Mass production of rotifers. Austasia Aquac. Mag. 1989, 3, 6-7.

61. Chester, A.J. Microzooplankton in the Surface Waters of the Strait of Juan de Fuca. NOAA Technical Report ERL-403-PM. 1978, p. 26. Available online: http://citeseerx.ist.psu.edu/viewdoc/download?doi=10.1.1.514. $763 \&$ rep $=$ rep1\&type $=$ pdf (accessed on 13 January 2020).

62. Dolan, J.R.; Gallegos, C.C. Trophic role of planktonic rotifers in the Rhode River Estuary, spring-summer 1991. Mar. Ecol. Prog. Ser. 1992, 85, 187-199. [CrossRef]

63. Fielder, D.S.; Purser, G.J.; Battaglene, S.C. Effect of rapid changes in temperature and salinity on availability of the rotifers Brachionus rotundiformis and Brachionus plicatilis. Aquaculture 2000, 189, 85-99. [CrossRef]

64. Fish, C.J.; Johnson, M.W. The Biology of the Zooplankton Population in the Bay of Fundy and Gulf of Maine with Special Reference to Production and Distribution. J. Biol. Board Can. 1937, 3, 189-322. [CrossRef]

65. Fradkin, S.C. Rotifer Distributions in the Coastal Waters of the Northeast Pacific Ocean BT-Rotifera IX; Sanoamuang, L., Segers, H., Shiel, R.J., Gulati, R.D., Eds.; Springer: Dordrecht, The Netherlands, 2001; pp. 173-177.

66. Guilini, K.; Levin, L.A.; Vanreusel, A. Cold seep and oxygen minimum zone associated sources of margin heterogeneity affect benthic assemblages, diversity and nutrition at the Cascadian margin (NE Pacific Ocean). Prog. Oceanogr. 2012, 96, 77-92. [CrossRef]

67. Holland, J.S.; Maciolek, N.J.; Kalke, R.D.; Mullins, L.; Oppenheimer, C.H. A benthos and plankton study of the Corpus Christi, Copano and Aransas Bay systems. In Report on Data Collected during the Period July 1973-April 1974; University of Texas Marine Science Institute: Port Aransas, TX, USA, 1974; p. 121.

68. Hopkins, T.L. The Plankton of the St. Andrew Bay System, Florida; Collections Galveston Bay Bibliography: Galveston, TX, USA, 1966; pp. 12-64.

69. Hopkins, T.L. Zooplankton distribution in surface waters of Tampa Bay, Florida. Bull. Mar. Sci. 1977, 27, 467-478.

70. Lee, W.Y.; Macko, S.A.; Ciereszko, L.S. Toxic effects of cembranolides derived from octocorals on the rotifer Brachionus plicatilis Müller and the amphipod Parhyale hawaiensis (Dana). J. Exp. Mar. Biol. Ecol. 1981, 54, 91-96. [CrossRef]

71. Martin, J.H. Phytoplankton-zooplankton relationships In Arragansett Bay 1. Limnol. Oceanogr. 1965, 10, 185-191. [CrossRef]

72. Myers, F.J. The rotifer fauna of Wisconsin. V. The genera Euchlanis and Monommata. Trans. Wis. Acad. Sci. 1930, 25, 353-413.

73. Sellner, K.G.; Lacouture, R.V.; Cibik, S.J.; Brindley, A.; Brownlee, S.G. Importance of a winter dinoflagellate-microflagellate bloom in the Patuxent River estuary. Estuar. Coast. Shelf Sci. 1991, 32, 27-42. [CrossRef]

74. Sommer, S.; Gutzmann, E.; Ahlrichs, W.; Pfannkuche, O. Rotifers colonising sediments with shallow gas hydrates. Naturwissenschaften 2003, 90, 273-276. [CrossRef] [PubMed] 
75. Sommer, S.; Gutzmann, E.; Pfannkuche, O. Sediments hosting gas hydrate: Oases for metazoan meiofauna. Mar. Ecol. Prog. Ser. 2007, 337, 27-37. [CrossRef]

76. Suchar, V.A.; Chigbu, P. The effects of algae species and densities on the population growth of the marine rotifer, Colurella dicentra. J. Exp. Mar. Biol. Ecol. 2006, 337, 96-102. [CrossRef]

77. Tunnell, J.W., Jr.; Alvarado, S.A. Checklist of Species within Corpus Christi Bay National Estuary Program Study Area: References, Habitats, Distribution, and Abundance; Corpus Christi Bay National Estuary Program CCBNEP-06D; Texas National Resource Conservation Commission: Austin, TX, USA, 1996; p. 298.

78. Winder, M.; Jassby, A.D. Shifts in zooplankton community structure: Implications for food web processes in the upper San Francisco Estuary. Estuar. Coasts 2011, 34, 675-690. [CrossRef]

79. Jersabek, C.D.; Segers, H.; Dingmann, B.J. The Frank J. In Myers Rotifera Collection; The Whole Collection in Digital Images; The Academy of Natural Sciences of Philadelphia, Special Publication 20: Philadelphia, PA, USA, 2003.

80. De Smet, W.H. Rotifera from the Mediterranean Sea, with description of ten new species. Zootaxa 2015, 4028, 151-196. [CrossRef]

81. Sørensen, M.V.; Kristensen, R.M. Marine Rotifera from Ikka Fjord, SW Greenland. With the description of a new species from the rare mineral ikaite. Meddelelser Om Grønland Bioscience 2000, 51, 46.

82. Althaus, B. Neue Sandbodenrotatorien aus dem Schwarzen Meer. Wiss. Z. Univ. Halle Math. Nat. 1957, 6, 445-458.

83. Jersabek, C.D. The 'Frank J. Myers Rotifera collection' at the Academy of Natural Sciences of Philadelphia BT-Rotifera X: Rotifer Research: Trends, New Tools and Recent Advances. In Proceedings of the International Rotifer Symposium, Illmitz, Austria, 7-13 June 2003; Herzig, A., Gulati, R.D., Jersabek, C.D., May, L., Eds.; Springer: Dordrecht, The Netherlands, 2005; pp. 137-140.

84. De Ridder, M.; Segers, H. Monogonont Rotifera Recorded in the World Literature (Except Africa) from 1960 to 1992 ; KBIN: Bruxelles, Bélgica, 1997; Volume 88, pp. 3-481.

85. Litton, J.R. The marine interstitial and planktonic rotifer fauna of Puerto Rico. Proc. Indiana Acad. Sci. 1982, 92,470 .

86. Wilke, T.; Ahlrichs, W.H.; Bininda-Emonds, O.R.P. A weighted taxonomic matrix key for species of the rotifer genus Synchaeta (Rotifera, Monogononta, Synchaetidae). Zookeys 2019, 871, 1-40. [CrossRef]

87. Hollowday, E.D. Family Synchaetidae Hudson and Gosse, 1886. Rotifera 6: Asplanchnidae, Gastropodidae, Lindiidae, Microcodidae, Synchaetidae, Trochosphaeridae and Filinia. In Guides to the Identification of the Microinvertebrates of the Continental Waters of the World; Nogrady, T., Ed.; Backhuys Publishers: Leiden, The Netherlands, 2002; pp. 87-211.

88. De Smet, W.H. Cotylegaleatidae, a new family of Ploima (Rotifera: Monogononta), for Cotylegaleata perplexa gen. et sp. nov., from freshwater benthos of Belgium. Zootaxa 2007, 1425, 35-43. [CrossRef]

89. Peters, F. Untersuchungen über Anatomie und Zellkonstanz von Synchaeta (S. grimpei Remane, S. baltica Ehr., S. tavina Hood und S. triophthalma Laut). Ein Beitrag der Artunterschiede bei konstantzelligen Tieren. Zeitschrift Für Wissenschaftliche Zoologie 1931, 139, 1-119.

90. Remane, A. Rotatoria (4. Lieferung). HG Bronn's Klassen und Ordnungen desTier-Reichs. In Vierter Band Vermes. II; Abteilung Aschelminthen. I. B. Rotatorien, Gastrotrichen und Kinorhynchen; Akademische Verlagsgesellschaft: Leipzig, Germany, 1933; pp. 452-576.

91. Spalding, M.D.; Fox, H.E.; Allen, G.R.; Davidson, N.; Ferdana, Z.A.; Finlayson, M.; Halpern, B.S.; Jorge, M.A.; Lombana, A.; Lourie, S.A. Marine ecoregions of the world: A bioregionalization of coastal and shelf areas. BioScience 2007, 57, 573-583. [CrossRef]

92. Friedrich, C.; De Smet, W.H. The rotifer fauna of arctic sea ice from the Barents Sea, Laptev Sea and Greenland Sea. Hydrobiologia 2000, 432, 73-90. [CrossRef]

93. Devetter, M.; Fontaneto, D.; Jersabek, C.D.; Mark Welch, D.B.; May, L.; Walsh, E.J. Preface: Evolving rotifers, evolving science. Hydrobiologia 2017, 796, 1-6. [CrossRef]

94. Obertegger, U.; Flaim, G. Taxonomic and functional diversity of rotifers, what do they tell us about community assembly? Hydrobiologia 2018, 823, 79-91. [CrossRef]

95. Mills, S.; Alcántara-Rodríguez, J.A.; Ciros-Pérez, J.; Gómez, A.; Hagiwara, A.; Galindo, K.H.; Jersabek, C.D.; Malekzadeh-Viayeh, R.; Leasi, F.; Lee, J.-S.; et al. Fifteen species in one: Deciphering the Brachionus plicatilis species complex (Rotifera, Monogononta) through DNA taxonomy. Hydrobiologia 2016, 796, 39-58. [CrossRef] 
96. Martínez, A.; Di Domenico, M.; Leasi, F.; Curini-Galletti, M.; Todaro, M.A.; Zotto, M.D.; Gobert, S.; Artois, T.; Norenburg, J.; Jörger, K.M.; et al. Patterns of diversity and endemism of soft-bodied meiofauna in an oceanic island, Lanzarote, Canary Islands. Mar. Biodivers. 2019, 49, 2033-2055. [CrossRef]

97. Rougier, C.; Pourriot, R.; Lam-Hoai, T. The genus Synchaeta (rotifers) in a north-western Mediterranean coastal lagoon (Etang de Thau, France): Taxonomical and ecological remarks. Hydrobiologia 2000, 436, 105-117. [CrossRef]

98. Fonseca, V.G.; Carvalho, G.R.; Nichols, B.; Quince, C.; Johnson, H.F.; Neill, S.P.; Lambshead, J.D.; Thomas, W.K.; Power, D.M.; Creer, S. Metagenetic analysis of patterns of distribution and diversity of marine meiobenthic eukaryotes. Glob. Ecol. Biogeogr. 2014, 23, 1293-1302. [CrossRef]

99. Carugati, L.; Corinaldesi, C.; Dell'Anno, A.; Danovaro, R. Metagenetic tools for the census of marine meiofaunal biodiversity: An overview. Mar. Genom. 2015, 24, 11-20. [CrossRef] [PubMed]

100. Gómez, A.; Carmona, M.J.; Serra, M. Ecological factors affecting gene flow in the Brachionus plicatilis complex (Rotifera). Oecologia 1997, 111, 350-356. [CrossRef] [PubMed]

101. Khlebovich, V.V.; Aladin, N.V. The salinity factor in animal life. Her. Russ. Acad. Sci. 2010, 80, $299-304$. [CrossRef]

102. McNamara, J.C.; Faria, S.C. Evolution of osmoregulatory patterns and gill ion transport mechanisms in the decapod Crustacea: A review. J. Comp. Physiol. B 2012, 182, 997-1014. [CrossRef]

103. Leasi, F.; Andrade, S.C.D.S.; Norenburg, J. At least some meiofaunal species are not everywhere. Indication of geographic, ecological and geological barriers affecting the dispersion of species of Ototyphlonemertes (Nemertea, Hoplonemertea). Mol. Ecol. 2016, 25, 1381-1397. [CrossRef]

104. Leasi, F.; Gaynus, C.; Mahardini, A.; Moore, T.N.; Norenburg, J.L.; Barber, P.H. Spatial and ecologic distribution of neglected microinvertebrate communities across endangered ecosystems: Meiofauna in Bali (Indonesia). Mar. Ecol. 2016, 37, 970-987. [CrossRef]

105. Lefeuvre, J.-C.; Laffaille, P.; Feunteun, E.; Bouchard, V.; Radureau, A. Biodiversity in salt marshes: From patrimonial value to ecosystem functioning. The case study of the Mont-Saint-Michel bay. C. R. Biol. 2003, 326, 125-131. [CrossRef]

106. Visser, J.M.; Midway, S.; Baltz, D.M.; Sasser, C.E. Chapter 15-Ecosystem Structure of Tidal Saline Marshes; Perillo, G.M.E., Wolanski, E., Cahoon, D.R., Hopkinson, C.S.B.T.-C.W., Eds.; Elsevier: Amsterdam, The Netherlands, 2019; pp. 519-538.

107. Akter, R.; Asik, T.Z.; Sakib, M.; Akter, M.; Sakib, M.N.; Azad, A.; Alauddin, A.S.M.; Maruf, M.; Haque, A.; Rahman, M. The dominant climate change event for salinity intrusion in the GBM Delta. Climate 2019, 7, 69. [CrossRef]

108. Zeppilli, D.; Sarrazin, J.; Leduc, D.; Arbizu, P.M.; Fontaneto, D.; Fontanier, C.; Gooday, A.J.; Kristensen, R.M.; Ivanenko, V.N.; Sørensen, M.V. Is the meiofauna a good indicator for climate change and anthropogenic impacts? Mar. Biodivers. 2015, 45, 505-535. [CrossRef] 